University of Louisville

ThinkIR: The University of Louisville's Institutional Repository

\title{
The priorities and accomplishments of Kentucky legislators : is there a gender difference?
}

Amanda Allen

Follow this and additional works at: https://ir.library.louisville.edu/honors

Part of the Feminist, Gender, and Sexuality Studies Commons, Gender and Sexuality Commons, Law and Gender Commons, Law and Politics Commons, Political Science Commons, and the State and Local Government Law Commons

\section{Recommended Citation}

Allen, Amanda, "The priorities and accomplishments of Kentucky legislators : is there a gender difference?" (2016). College of Arts \& Sciences Senior Honors Theses. Paper 114.

http://doi.org/10.18297/honors/114

This Senior Honors Thesis is brought to you for free and open access by the College of Arts \& Sciences at ThinkIR: The University of Louisville's Institutional Repository. It has been accepted for inclusion in College of Arts \& Sciences Senior Honors Theses by an authorized administrator of ThinkIR: The University of Louisville's Institutional Repository. This title appears here courtesy of the author, who has retained all other copyrights. For more information, please contact thinkir@louisville.edu. 
The Priorities and Accomplishments of Kentucky Legislators: Is There a Gender Difference?

By

Amanda Allen

Submitted in partial fulfilment of the requirements for Graduation summa cum laude

and

for Graduation with Honors from the Department of Political Science

University of Louisville

March 2016 
Table of Contents

\begin{tabular}{|c|c|}
\hline Section Title & Page Number \\
\hline Acknowledgements & 3 \\
\hline Abstract & 4 \\
\hline Introduction & 5 \\
\hline Literature Review & 6 \\
\hline Hypotheses & 15 \\
\hline Methodology & 16 \\
\hline Results & 20 \\
\hline Limitations & 33 \\
\hline Conclusion & 34 \\
\hline Further Research & 39 \\
\hline Works Cited & 41 \\
\hline Figures & 45 \\
\hline Tables & 58 \\
\hline Appendix A & 61 \\
\hline Appendix B & 62 \\
\hline
\end{tabular}




\section{Acknowledgements}

I would like to thank several individuals for support, guidance, and advice on my thesis:

Dr. Jasmine Farrier (Advisor), Dr. Laura Moyer (Thesis Committee Second Reader), Dr. Amy Clukey (Thesis Committee member), Julie Kroger, Dana Mayton, Jacqueline Coleman, Mary Elizabeth Young, Benjamin Leamon, Vivien Pham, Dr. Sherrie Wallace, Dr. Jason Gainous, Daniel Waqar, Victoria Ochoa, Erin Dugan, and Dr. Andrew Rich. 


\begin{abstract}
This thesis uses Kentucky as a case study of gender differences in the policy priorities and perceptions of accomplishments of state legislators. The research question is, "are there gender differences in the legislative priorities and perceptions of accomplishments of Kentucky legislators?" The legislative priorities of the legislators seemed to be similar, along with their own classification of women's issues. The perceptions of success demonstrated that male legislators were not necessarily more likely to attribute success to themselves, whereas women would attribute success to collaboration efforts. The research was completed through confidential interviews with Kentucky legislators and analysis of the 2015 legislative session bill data. The study of gender differences in policy priorities and perceptions of accomplishments of state legislators is an opportunity to gain insight on the effects of having few women in the state legislature.
\end{abstract}

\title{
Lay Summary
}

As the number of women legislators increased, more researchers became interested in gender differences in legislative behavior. There is now a wealth of information on the similarities and differences between men and women legislators on the state and national level. This thesis uses interview data and state legislative bill data to investigate the gender differences in Kentucky legislators regarding legislative priorities and perception of accomplishments. The similarities of the legislative priorities and the legislators' similarities in the classifications of women's issues were supported by the data. 


\section{The Priorities and Accomplishments of Kentucky Legislators: Is there a Gender Difference?}

\section{INTRODUCTION}

This undergraduate senior thesis aims to assess the impact of gender on legislative priorities and self-perception of success of Kentucky state legislators. While there is a range of research on women in state and national politics, no studies exist on Kentucky's women legislators regarding their legislative priorities and perception of accomplishments and how/whether they conform to the literature.

This thesis reviews the research on theories of representation to provide background on research about women's representation as legislators, which is important to frame the research on gender differences in legislative priorities. Next, the literature on women's issues investigates the debate about what women's issues mean and how they have any relevance today. This research is also important to understand if there are any gender differences in legislative priorities or if it is more complicated than that due to our multifaceted identities (gender, race, sexual orientation, socioeconomic status). To provide a point of comparison, it is important to examine research on the United States Congress and gender differences in legislative priorities along with research on Congress and gender differences in legislative accomplishments. Also, examining state legislatures and gender differences in legislative priorities and accomplishments is necessary to understand where Kentucky might fit in existing theories and data.

Kentucky will be used as the case study because it is my home state and Kentucky has a low number of women in its legislature (16\% of the General Assembly) in comparison to the national average. This difference provides an opportunity to explore if the pressures of 
underrepresentation impact legislative priorities. It also presents challenges in that there are no literature on Kentucky women legislators.

Nevertheless, now is a good time to update research, test existing assumptions about policy specialization, and open up a new area of research on legislators' perceptions of legislative success. The main method is field research via interviewing Kentucky legislators and quantitative supplement data from the Kentucky Legislative Research Commission. As a result of the data, we can conclude: First, that the legislative priorities of Kentucky women legislators are similar to Kentucky male legislators, Second, there is uniformity in how, and if, their legislative priorities are as women's issues. Finally, male legislators are not more likely to attribute success to themselves and women are equally as likely as males to attribute success to collaboration efforts.

\section{LITERATURE REVIEW}

\section{REPRESENTATION}

Representation is a multifaceted concept that political scientists and theorists have studied since the time of philosophers such as Thomas Hobbes and John Locke. As political scientist Hanna Pitkin says, “...representation does have an identifiable meaning, applied in different but controlled and discoverable ways in different contexts. It is not vague and shifting, but a single, highly complex concept that has not changed much in its basic meaning since the seventeenth century" (1972, p.4). In other words, representation comes in many shapes and forms, but it has the same meaning of "to present again."

When it comes to gender, women's representation has both descriptive and substantive components. Descriptive representation is the idea that representatives represent those of similar backgrounds and demographics (e.g., women representing women), whereas substantive 
representation is the idea that representatives can advocate on behalf of broader constituents and policy interests. Despite clear gains in numeric representation, women are still not represented in proportion to the population. Since the 1980s, the number of women in Congress has tripled, yet women still make up only 19\% of Congress today (Center for American Women in Politics 2015). As of 2015, women make up $24.4 \%$ of all state legislatures in the United States, which is obviously only slightly better than the Congressional make up of women (National Conference of State Legislatures).

Descriptive representation is a potent symbol of political legitimacy for any historically disadvantaged group, which is important because often times "women legislators bring 'women's issues' to the table and with more women legislators in office, it makes government policies more responsive to the interests of most women" (Mansbridge 1999, p. 647). This could mean a difference in what legislative policies women legislators prioritize in comparison to men. In fact, in a published 2005 research article, Mansbridge says, "descriptive representation by gender improves substantive outcomes for women in every polity for which we have a measure" (p. 622). To put it another way, women representing women in legislative bodies produces positive outcomes for women such as having issues that disproportionally effect women be represented legislatively.

\section{WOMEN'S ISSUES}

Researchers have found that simply categorizing certain issues as women's issues is not sufficient because the exact meaning of the term is contested in the literature. In the past, scholars and researchers thought there were defined women's issues, but the field has evolved to where women's issues must be viewed as "complex, varied, in flux, and divergent" (Smooth, 2011, p. 440). Another concern with defining the term is that women's issues differ based on 
context because women's experiences are "socially constructed" and "vary based on specific process of construction" (Beckwith, 2007, p.554). The intersection of gender and other identities like race complicate what are considered women's issues as well (Beckwith 2007). The term problematically suggests that the work of women legislators is narrow. In reality, female legislators, like males, form preferences and influence the legislative process on a range of issues for a variety of reasons (Jeydel and Taylor 2003).

Furthermore, this problem leads to questions surrounding women representing women's issues. Research suggests that gender can affect the behavior and actions of legislators in Congress. For example, research indicates that women sponsor women's issues bills (Volden, et al. 2013). The most common women's issues referred to in the research literature are "abortion, education, health care, and welfare" (Jeydel and Taylor 2003, p. 19). Women are not only more likely to sponsor women's issues bills, but also are more likely to vote on women's issues across party lines (Volden, et al. 2013). In other words, women are more likely to agree on women's issues votes than men on the same issues. There is evidence "that in the cases of gender and race, legislators who themselves are members of a group respond to issues affecting that group with greater concern than do nonmembers" (Mansbridge 2005, p. 624). In fact, research shows that differences in gender between legislators is evident in issues that legislators spend the most time and energy on "such as choice of committees to join and legislation to sponsor" (Mansbridge, 2005, p. 625).

\section{CONGRESS: LEGISLATIVE PRIORITIES AND LEGISLATIVE SUCCESS}

There is scholarly evidence that congresswomen disproportionately influence the congressional policymaking process, especially on women's issues. Congresswomen are doing this by sponsoring and cosponsoring legislation relating to women's issues more than 
congressmen. To bring women's issues to the forefront, congresswomen are using their committee positions and participating in floor debates on these issues (Swers 2001). While issue specialization seems to help women in Congress be effective legislators, women are less likely to find legislative success than their male colleagues in Congress (Volden, et al. 2013). Volden, Wiseman, and Wittmer also found in their research that congresswomen do not receive deference on women's issues and that women's issues are more likely to be stuck in legislative gridlock (2013). While women may not find as much success as their male colleagues in Congress, it is evident there are some tools that congresswomen leverage to be effective.

In regards to legislative success, Jeydel and Taylor cited in their research that other scholars have found that women state legislators are more successful than male state legislators. This includes issues that are not considered women's issues. In fact, when it comes to legislative accomplishments in the House of Representatives, gender differences are narrow and subtle than previous research had suggested in regards to the legislative effectiveness of women. In fact, Jeydel and Taylor suggest that effectiveness is a function of seniority and membership to important House institutions such as the majority party or influential committees (2003).

There is much literature on the significant differences in political behaviors in this respect, with women being more collaborative and men being more individualistic and competitive (Volden, et al. 2013). It has been found that female legislators are more likely than male legislators to co-sponsor legislation, one form of collaboration (Swers 2005). Even when controlling for ideology, women are more likely to co-sponsor legislation concerning women's issues with each other, "especially in a bipartisan fashion" (Clark and Caro 2013, p. 25). In comparison, current research says that male senators are more eager to participate in "credit claiming" (claiming responsibility for a desirable governmental outcome) regardless of the issue 
because men are more likely to take credit for their own accomplishments (Thomas 2005, p. 89). In fact, male senators rank higher than women on both women's issues and "male issues" in claiming credit. Quantitative research such as the credit claiming research could be different if examined through the lens of self-perception of success. In other words, there may be a difference by gender in how legislators personally view their own success. This is important because it differs from the typical quantitative measures of success such as bill passage rates by gender. Self-perception will add depth to our understanding of what legislators think about success, which is important because while their actions (i.e. credit claiming) may say they are successful or not, their personal views on success could shed more light on the why behind those actions.

\section{WOMEN IN STATE LEGISLATURES}

The next set of relevant literature is on women in state legislatures. In 2015, women made up about $24 \%$ of state legislatures. Interestingly, $60 \%$ of the women are Democrats and $39 \%$ of the women are Republicans. Even states with the highest percentage of women do not have more than $50 \%$ of women in their state legislatures (Center for American Women and Politics 2015).

Next, some scholars have determined that women legislators have policy differences from men (Thomas 1991). Over time, as the number of women in the state legislature approached a critical mass, the sex differences in the policy priorities of state lawmakers intensified (Swers 2001). On the other hand, researchers have found that even where women make up less than $15 \%$ of the membership, they were able to represent women interests effectively, and because of that, they concluded that a critical mass was not necessary for substantive representation by women legislators. In fact, "gender differences in agenda-setting 
behavior in some states narrow as the percentage of women in the legislature increases" (Bratton 2002). However, other research indicates that these differences intensify as the number of women in the legislature increases (Swers 2001). It is a good time to investigate how Kentucky legislators fit in the literature, especially since Kentucky has a partisan mix in statewide offices, meaning that, unusually, our state wide elected officials consist of Democrats and Republicans.

\section{KENTUCKY WOMEN IN THE LEGISLATURE}

Kentucky is among the states with the lowest percentage of women in state legislatures, with about $16 \%$ female representation. Kentucky is ranked as $43^{\text {rd }}$ in the number of women in its state legislature. To provide a frame of reference, states such as Colorado (42\%), Vermont (41\%), Arizona (36\%), Washington (34\%), Minnesota (34\%), Nevada (33\%), Illinois (33\%), Maryland (32\%), Montana (31\%), and Oregon (31\%) are the top 10 states for the number of women represented in its legislature (Center for American Women in Politics 2015). States such as Louisiana (13\%), Wyoming (13\%), Oklahoma (14\%), South Carolina (14\%), Alabama (14\%), West Virginia (15\%), Utah (15\%), Virginia (17\%), and Mississippi (17\%) are the bottom 10 states for the number of women represented in its legislature, also including Kentucky (Center for American Women and Politics 2015). Most of the bottom states are concentrated in the southern region of the United States. Figure 1 could mean that there are even regional differences for the number of women in state legislatures and the reasoning behind that as well.

[Figure 1 here]

Out of the United States' state legislative bodies, women represent $24.5 \%$ of state level representatives. In the state senates, women hold $22.5 \%$ of the seats and $25.3 \%$ of the House seats. There are a total of 7,383 state legislators in the United States as of 2015. Since 1971, "the number of women serving in state legislatures has more than quintupled over time." In a further 
breakdown, in the 2015 legislative session, there are 4 out of 38 (10.5\%) women in the Kentucky Senate with 2 Democrats and 2 Republicans. In the Kentucky House, 19 out of 100 (19\%) representatives are women, with 11 Democrats and 8 Republicans (Center for American Women and Politics 2015). It is evident the in the Kentucky House, women make up a larger portion of lawmakers than in the Senate.

\section{$\underline{\text { STATE LEGISLATURES AND POLICY PRIORITIES }}$}

There has been some, but not much, research on comparing male and female state legislators' policy priorities and their significant areas of accomplishment (Thomas and Welch 1991). However, in the available research, scholars examining policy preferences across state legislatures indicate that women legislators are more likely than male legislators to take liberal positions, and women are more likely to support the feminist side of such women's rights issues, even when controlling for party and district level factors (Cammisa and Reingold 2004). Liberal is defined in the sense of U.S. political ideology and feminist is defined as pursing agendas that promote the equality of males and females. Hogan has found that there are gender differences in roll-call voting behavior regarding economic and regulatory policy specifically among the Democrats, whereas research in the past has shown greater differences among Republicans (2008).

Additionally, policy preferences of lawmakers relate to their own expertise in particular policy areas. Barret describes a study in her research where women state legislators were interviewed regarding familiarity with policy topics. While many legislators felt their expertise went across a broad range of policy areas, the female lawmakers who specified particular areas of their expertise noted health, education, and welfare policy. Very few legislators noted policy expertise in other areas such as fiscal affairs, agriculture, business, and public works; in fact, it 
was only $12 \%$ or less in each area (Barret 1995). Moreover, there is evidence that within the issue of welfare, there is a gender difference. One study concluded that women state legislators are more likely to hold liberal preferences in welfare policy than men, even accounting for characteristics like party, despite the concern that constituency demands may constrain women representing conservative districts (Poggione 2004). In Kentucky, women legislators could be impacted in similar ways in that constituency demands could affect their legislative priorities. However, it is interesting to note that there is a prominent gap in the literature that examines if these conclusions hold for women legislators in electorally conservative states like Kentucky. While most of the research for this paper includes data from liberal and conservative states mixed together, none of them focused on conservative states or even women in conservative states for that matter. Conservative states are defined as those states that are identified as such in the 2014 Gallup survey on the "State of the States." In the Gallup measure, Kentucky is considered "above-average conservative." While this research will focus only on Kentucky, it could be an opportunity to provide insight to investigate if these conclusions apply to women legislators in other conservative states.

Within the realm of research on women's issues in the traditional sense of phrase, women in leadership in state legislatures are more likely to prioritize "issues of traditional concern to women: health care, social services, women's family and children issues, and the environment." In comparison, they are less likely than men to prioritize "taxes, budget matters, public safety, institutional regulation and matters of insurance or product liability" (Little et al. 2001, p. 11). In the same study, the gender difference in state legislators' policy priorities "remain significant when controlled for party, race, experience, type of leadership position and region." Overall, the study suggests that as the number of women in the state legislature increases over time, women 
legislators are increasingly advocating for policies different from those that men tend to focus on. There is evidence that demonstrates that women are more likely than men to serve on chair committees dealing with traditional women's interests (e.g. education, health, welfare) and less likely to serve on committees dealing with business and fiscal issues. Committee assignments are important because they can influence legislative priorities of state legislators (Little et al. 2001, p.5).

\section{$\underline{\text { STATE LEGISLATURES AND LEGISLATIVE SUCCESS }}$}

In one study, there are three categories associated with state-level legislative success: institutional, personal, and environmental. Within the institutional category, holding a formal legislative position (committee chair, leadership, etc.), seniority, and majority party status have been linked to success. Within the personal category, certain attributes such as education, occupation, race, gender, and age are linked to success. Finally, environmental factors such as the safety of the legislator's district and the type of district also influence legislative success (Ellickson 1992).

Another substantive area where researchers measure legislative success is by bill success. However, success by gender varies by state. For example, in Maryland "women are significantly less likely than men to achieve passage of the legislation they introduce, whereas in California, women are significantly more likely than men to achieve passage of the legislation they introduce" (Bratton and Haynie 1999, p. 672). The literature on state legislatures says that "women report spending more time engaging in building within-party and across-party coalitions than men," which makes women "team players" and demonstrates that there are specific legislative gender differences in activities that relate to communication and compromise (Volden, et al. 2013). 


\section{JUSTIFICATION FOR RESEARCH}

Ultimately, the literature suggests that the way legislators see women's issues is not simple. Also, the research on policy priorities indicates that women, even controlling for party, tend to take more liberal stances on women's issues. Furthermore, women have indicated that they feel more comfortable in issue areas that are traditional women's issues. However, there are notable gaps in the literature as well. For example, research indicates that women can be just as successful, if not more successful, than their male colleagues, but this research will attempt to further open an area about legislators' self-perception of legislative success. Self-perception of legislative success is the legislator's personal views about their success. The literature does not indicate if legislators' own thoughts on success align with the results of quantitative measures such as bill passage rates. In this thesis, I test whether these factors provide leverage on understanding legislative behavior in Kentucky and states with similar political culture and institutional makeup.

\section{HYPOTHESES}

The literature indicates that there is a gender difference among state legislators in their policy priorities. Also, there is significant research on the role of gender and women's issues on the effect of descriptive representation on legislators representing who they are (women representing women). In other words, researchers have found that women representing women has indeed assisted women, but in other ways the expectations women's issues have narrowed and pigeon-holed the role of female lawmakers. Finally, while there are some data on gender differences in legislative success, this is a new opportunity to understand the Kentucky legislators' own perception of success because there appears to be significantly less research on 
legislators' personal perception of success. Overall, none of the research speaks toward Kentucky.

This led to the research question of "The Priorities and Accomplishments of Kentucky Legislators: Is there a Gender Difference?" Within in this question, I tested the following hypotheses:

H1: The legislative priorities of Kentucky women legislators will be similar to Kentucky male legislators because of constituency constraints. As previously stated, research demonstrates that female lawmakers take the liberal side of issues controlling for party. If female lawmakers in Kentucky fit the literature, then the ideology of the constituency of the lawmakers could pose limitations on a female legislator.

$\mathrm{H} 2$ : There will not be uniformity in how and if legislators classify their legislative priorities as "women's issues."

H3: Male legislators will be more likely to attribute success to themselves and women will be more likely to attribute success to collaboration efforts that involve others.

\section{METHODOLOGY}

The primary research method was conducting confidential interviews with male and female Kentucky legislators in both the House and Senate, which is collectively known as the General Assembly. Notes for the interviews were taken by hand or typed and were not audiorecorded. The choice to not audio-record the interviews reduced the subject perception of risk in the Institutional Review Board evaluation. In turn, it may have eased recruitment efforts as well. The interview portion was conducted from September 2015 to January 2016. The interviews followed the responsive interviewing model with open and closed format questions, which included 5 point Likert scales. The responsive interview model relies on the belief that the goal 
of the research is to produce a depth of understanding about the subject as opposed to breadth. The interviews in this model call on the subjects' interpretation of their experiences and their understanding of those experiences. Also, this interview design is flexible in that the questions can be shaped by the subjects' own interpretation and understanding of their experiences (Rubin and Rubin, 2005).This model a good fit was because investigating self-perception requires the participants own views of their experiences.

Legislators were contacted via email and the interviews were conducted via phone and in-person (see Appendix A). Appendix B contains a copy of the interview questions. The legislators were difficult to contact and it took several email attempts, and sometimes phone calls, to discuss their participation in the research project. As a result of this difficulty, I did use my personal connections to assist in getting interviews because it was important to reach my goal of at least 10 interviews.

Nevertheless, interviews serve as an important research tool in political science. Qualitative interview methods allow a researcher to examine a complex question or problem with depth that quantitative methods do not allow (Rubin and Rubin 2005). In fact, they "are an important and distinct means of understanding contemporary political actions and outcomes" (Mosley 2013, p. 5). A clear example of the value of this research method can be seen in Richard Fenno's Home Style: House Members in their Districts (1978). Fenno uses participant observation to describe how legislators perceive and present themselves to their constituency. He interviews House of Representative members and uses the interviews to reinforce his points. The interviews are simply quoted when appropriate in the text to illustrate analytical points. The interview report method for this research follows Fenno's style. Since this thesis relies on 
legislators' own perceptions to answer the research question, the interviews are an essential method.

The interviews investigated the legislative priorities of each subject, their perceptions of success, and their views on specific gender aspects to politics. The goal was to get data from a balanced number of 10-15 interviewees total, including both political parties and both legislative chambers. Another goal was obtaining representation from all five Kentucky geographical regions, which include the Cumberland Plateau, Bluegrass Region, Pennyroyal Region, Western Coal Field, and Jackson Purchase Region ("Physiographic - Kentucky Atlas and Gazetteer"). Trying to have subjects from both political parties was an attempt to control for ideology. Different regions can have different policy priorities and party membership concentration. For example, Louisville is heavily Democratic, so legislators from this area are generally Democrats. In contrast, subjects in the Bluegrass Region were from a variety of places across the Bluegrass Region. Finally, trying to have a balanced number of men and women was important because gender is the independent variable.

This interview method faced many of the difficulties outlined by Layna Mosley in her book Interview Research in Political Science (2013), such as the representativeness of the sample, the quality of information obtained, and the accuracy of reporting (p. 86-89). First, the research sample was not completely ideal. It is difficult to determine the representativeness of my sample size because it is so small. Within the small sample, I also had to try to account for and balance for gender, party, chamber, and geographic region. Next, partially selecting my sample to increase interview response rate prevented me from doing random sampling.

A supplemental research method included the Kentucky Legislative Research Commission (LRC), which is the non-partisan research and data gathering body of the Kentucky 
Legislature (http://www.lrc.ky.gov/ ). The additional data includes bill tracking to study bill sponsorship, the bill committee assignment, and bill passage of male versus female legislators to look at priorities and success. These data included all of the bills from House and Senate in the 2015 legislative session. The bills were used to quantify any gender differences in legislative priorities and legislative success. Quantifying gender differences is important since the literature indicates that gender difference in these regards (i.e. gender differences in bill passage, bill sponsorship, etc.) may vary across states. The study did not include resolutions because resolutions are an expression or opinion of the chambers not substantive law or statute (Legislative Research Commission).

The LRC did not have the information that was needed for the quantitative portion of this thesis. As a result, bill information was independently gathered from the LRC website and processed in Microsoft Excel. Next, if the bill was pre-filed, the committee assignment of the bill during the legislative session was documented and coded in Excel. Due to time constraints and limited manpower, only data from the 2015 legislative session was studied. Although examining data from previous legislative sessions would have allowed for more generalization, the 2015 legislative session is a start to demonstrate its value in conducting future research that includes more legislative session years.

The statistical computing was conducted using the " $\mathrm{R}$ " statistical software, which is a free open source software. In conjunction with the "R" program, I used the text called $A n$ Introduction to Statistical Computing for the Social Science Using $R$ by Dr. Jason Gainous. The text provided instructions on how to use the software and for interpreting various types of data. The program allowed me to take measurements, such as calculated measures of central tendency and frequency distributions. 
Overall, both the qualitative and the quantitative data were used to test the hypothesis regarding the legislative priorities of men and women. The interviews provided subjective information about the legislators' own perception of their priorities, while the quantitative data provided more objective indicators of legislative activity and success.

\section{RESULTS}

The result discussion consists of two parts: the interview data and the quantitative data that was used in this case study. Within the interview data, information will be presented in the following order: first, discussion of the participant make-up; then, discussion of the results of the interviews in the subsections of legislative priorities, legislative success, and gender; finally, the results of the quantitative data analysis of the bills from the 2015 legislative session.

\section{PARTICIPANT MAKE-UP}

A total of 10 interviews were completed. The interviews were completed via phone, inperson, and 1 written response. Five interviewees were men and 5 interviewees were women. There were 6 House of Representatives and 4 Senate interviewees. The total breakdown of participation can be viewed in Table 1. By party, there were 7 Democrat and 3 Republican participants. It was difficult to recruit Republican participants in either the House or Senate chambers, despite attempts to maintain a balance of party. The results may be skewed because 7 out of 10 of the respondents are Democrats, so the results may reflect as such. None of the women participants were Republican.

[Table 1 here]

Notably, there were no interview participants from the Western Coal Field and the Jackson Purchase Region. In fact, most of the interview participants were from the Bluegrass Region. This is not surprising because this is the region of my hometown Louisville, Kentucky, 
which made those legislators more accessible to participate in interviews. The concentration of participants in the Bluegrass Region will also affect the results because Louisville is a liberal area and the majority of participants were Democrats.

For gender, the participation was equal between men and women. The interviews at least achieved balance in this aspect, which was important because the primary variable that was of concern was a difference in gender among the legislators' responses. Again, they could be Democrat leaning responses because most of the women who participated were Democrats from the Bluegrass Region. In regards to chamber, the interviews were not balanced in this aspect either. 6 participants were from the House and 4 participants were from the Senate. To put it into perspective, there are significantly more house members than there are senate members. Ten point five percent of the Senate participated versus only $6 \%$ of the House.

\section{LEGISLATIVE PRIORITIES}

The first set of questions in the interview, which was divided into 4 questions, was about the interviewee's legislative priorities. The first two questions seemed to elicit similar responses. The first question asked about the policy areas that the legislator was knowledgeable about and comfortable handling, while the second question asked the legislator to narrow down the policy priorities to three areas only. The answers were similar because the legislators' three most important policy areas are the areas that they are knowledgeable about and comfortable handling. When the legislators were asked why, the responses elicited different answers.

\section{KNOWLEDGEABLE AND COMFORTABLE POLICY AREAS}

Regarding the first question, there seemed to be a slight difference in gender in the areas the legislators felt comfortable handling. The male participant responses tended to be in traditionally male-dominated issues such as economic development, agriculture, and finances. 
Two male legislators did list education as an area that they felt comfortable handling, an area traditionally viewed as a women's issue. As far as female legislators, their answers included a mix of policy areas that they felt comfortable handling, which included areas traditionally viewed as women's issues and policy that is traditionally male-dominated. Their answers included education, health and family, local government, economic development, veterans and military, and more. It is important to note that the responses of the women were so varied that it appears there is not any uniformity with the issue areas that the group of female interview participants felt comfortable handling.

The reasoning behind why legislators felt comfortable in certain issues was remarkably similar across genders. All of the legislators mentioned some kind of experience as the reasoning behind the issues areas they felt most comfortable handling. The types of experiences were most commonly previous work or previous legislative experience. For example, Participant C cited work in the education field, which influenced why education was a policy area that he was comfortable in. Participant H cited several years of committee experience (legislative experience) as the reason the legislator felt knowledgeable about veteran and military policy issues.

\section{MOST IMPORTANT LEGISLATIVE PRIORITIES}

The next question asked about the legislators' three most important policy priorities and why. One observation was that men and women both mentioned a mix of policy priorities including education, healthcare, and economic development. The female participants, as a whole, cited policy areas that were traditionally viewed as women's issues as often as they cited policy areas that have been viewed as male-dominated. The number of times women cited women's issues was equal to how often they cited male-dominated issues. While male legislators cited a 
mix of policy areas as a whole, they most often cited areas that are typically considered maledominated policy areas. Since the interview participants consisted of mostly Democrats, it was useful to attempt to observe if there intraparty difference. However, there were 2 Democrat men and 5 Democrat females, which make it difficult to make general observations for gender differences within the party. Yet, economics was mentioned by both men and 3 of the women. Other policy areas mentioned were diverse within Democrats across gender.

When discussing why their policy areas were important, the legislators gave responses that tied to a sense of community or making society a better place. The reasoning behind the legislators' policy areas also seemed to tie back to the issues that they claimed to feel most knowledgeable about and felt comfortable handling. For example, Participant $\mathrm{H}$ said that jobs were an important policy area for her because it "encompasses several things...represents the economy, it's a way to improve life for people, and our livelihood is tied up in jobs." In another example, Participant $\mathrm{G}$ said that she was interested in decreasing the number of people that we incarcerate because "it is better to keep people out of the criminal justice system and it is better for the community." The male legislators had similar responses. In response to why education was an important policy area, Participant E said that "where we go depends on a ready workforce and kids being college and career ready." For Participant E, the future of Kentucky depends on the aforementioned factors. In response to why economic development was an important policy area for him, Participant A said that "it is important to work and have jobs. Jobs make all the difference in the world to people and their ability to live a better life. When people can't find jobs it's hard."

INFLUENCES ON DETERMINING POLICY PRIORITIES 
The next question asked what the biggest influences were in determining the legislator's policy priorities. The influences seemed to fall into two categories: the legislators' constituency or an independent view of what should factor into their policy decisions. More often than not, male legislators cited their constituents as having some type of influence in their policy priorities. Participant A put it simply: “the people I represent and my priorities are..." what influences the determination of his policy priorities. Participant B had a more nuanced point of view of how his constituencies influence him in policy priorities. He believed that while it was important to represent his constituents first, at the end of the day, he has to vote using his conscience. It was surprising that there was a difference in how much their constituency played a role in the legislators' policy making decisions. This alludes to the delegate and trustee model of representation (Davidson, et.al 2014). Delegate representation is a description of activity based on the wants of their constituency, whereas trustee representation is decisions based on what they judge is best for their constituency.

The responses from the female legislators were more conceptual such as ethics. Participant G said, "Rule One is it right to do? Is it needed? And is it fiscally possible?" Participant F said that what influenced her was "focus on creating justice and beauty in the world to make a better community..." Two of the female participants did allude to their constituencies influence on their policy priorities. Participant I said that she looks for if "needs aren't being taken care of for the people, where there are solutions [to their needs]." Participant H said simply that the "people whom she represents" influences her determination of her policy priorities. ACTS TO TURN POLICY PRIORITIES INTO LEGISLATIVE ACTION

The final question in the legislative priorities section of the interview was about what the legislator had done to try to turn their priorities into legislative action. The answers were similar 
across gender. All of the legislators said they had proposed bills and worked to co-sponsor bills and gave specific examples of bills that they had proposed or co-sponsored.

\section{LEGISLATIVE PERCEPTION OF SUCCESS}

The next section of the interviews was about legislative perception of success. The first question explored the legislators' own definition of success in pursuing their legislative priorities. Also, this part of the interview included a Likert Scale to measure aspects that have contributed to a legislators' success.

\section{PERSONAL MEANING OF SUCCESS}

In regards to the first question on the legislators' definition of success, the female subjects had mixed responses that I would classify in two areas: tangible and intangible representations of success. Tangible aspects are ones in which the legislator mentioned a specific action that they could take (passing bills, blocking bills, etc.), whereas intangible aspects are ones that do not have a specific action associated with it, but rather an abstract idea (helping people, etc.).

Three of the female respondents described their success using intangible descriptions (i.e. making the community a better place), while only two of the female respondents described their success using tangible responses (i.e. passing a bill). In response to what success meant to them in pursuing their legislative priorities, the participants using intangible descriptions said that success meant "making the area I represent a better place to live and work", "moving agenda forward and not myself forward and making progressive values at the table in discussion during conservative times", and "making a difference." In comparison, female participants who gave tangible responses about what success meant to them said things such as "passage of good public 
policy..." and "to get laws, get something funded in the budget that wasn't funded before, bringing people to consensus, changing minds, or killing a bad bill.”

The male subjects elicited mix responses that, like the female responses, included tangible aspects and intangible aspects. Four out of five of the male participants cited tangible aspects in their definition of success. Participant D said that "... Success could mean helping get support or providing help with constituent services.” Participant E said, "There are the obvious ways of getting bills passed and there are less obvious ways such as voting against legislation...Success comes in a lot of ways, including helping one person.” Obvious ways could include voting against legislation and less obvious ways would be political strategy for example. This participant gave an example of an elderly couple that sent him a thank you email because he helped them with a Medicaid issue. In regards to this issue, the participant said, "helping bring government to people is success."

Participant B said that success means to him when "seeing those priorities implemented if that's the only measure you have, which can get frustrating...If you say you had a voice and crafted the final result, even with no name on the paper, it's okay because you still make a difference even when the party is in the minority." Finally, Participant A did cite intangible aspects by saying, "personal success is of no consequence. Success on legislation that improves people's lives means everything."

\section{LIKERT SCALE MEASURE OF SUCCESS}

[Table 2 here]

Table 2 will be used to examine the responses on the ten participants. A majority (7) of the participants, regardless of gender, said that personal initiative is very important to their success. Interestingly, legislators across the board thought it was important or somewhat 
important to their success. This included collaboration on committees, collaboration in the party, and collaboration in opposing the party. However, it is important to note that a cross tabulation of the results revealed that only the result for collaboration with fellow lawmakers in the party yielded a statistical significance. Also, when a difference of means test was conducted collaboration within committee yield a statistically significant difference, so males were on average more likely to say that collaboration with lawmakers on their committee was "very important."

Next, past experience saw some gender difference. The question was on a scale 5-point scale. The mean response for men was 2.4 while the mean response for women was a 1.4. Female respondents valued past experience slightly more than male respondents did. Similarly, the mean response for male respondents on professional experience was a 2, whereas the mean response for female respondents was a 1.2. While both men and women regarded professional experiences as either very important or somewhat important, women valued professional experience slightly higher. The difference in mean in these measures was not statistically significant.

\section{GENDER}

This section also included a mix of qualitative and quantitative questions that used a Likert scale. The first question asked, on a Likert scale, how strongly the legislator agreed with the statement that gender affects a legislator's success. The following question asked them to elaborate on their answer to the question. The third question in this section asked about what policy areas the legislator associated with women's issues to examine how the legislators associate gender with certain policy areas. The final question was a quantitative and asked about the frequency with which women's issues come up in a legislative session. 


\section{DOES GENDER AFFECT SUCCESS AS A LEGISLATOR? AND WHY?}

First, the question on how strongly the legislator thought gender affects their success produced interesting results. The results varied more within the female participants' answers while the results were more similar among male participants. Not surprisingly, most of the male participants said they disagreed or strongly disagreed. Four out of five of the male participants did not think that gender could affect a legislators' success. Only one male participant said that he neither agreed nor disagreed. This is not surprising because the Kentucky legislature is a male dominated institution. The variety in answer could be why with both the cross tabulation and difference in mean tests the results were not statistically significant.

\section{[Table 3 here]}

When male participants were asked to elaborate on their reasoning behind their answer, they seemed to believe that gender does not or should not impact a legislator's success. Participant A said, "It doesn't affect it and shouldn't affect it. Men and women are equal." Participant B said, “It doesn't matter if you are male or female. It mattered in the past, but now we are in a spot where it doesn't." This legislator cited examples such as having women as committee chairs and in leadership and said that he "would gladly vote for a woman if she is best for the job."

Similarly, Participant $\mathrm{C}$ gave examples such as how more women are running for office and how women are being recruited as candidates. He also named a female senator to whom he would give deference for guidance in the healthcare policy area because of her experience and not her gender. Participant D said that he "looks at policy and doesn't care who is behind the 
bill.” In another example, Participant E said that, "to say gender disadvantages a legislator goes too far." But he further elaborated by concluding while he can see there are some disadvantages if a legislator is female, those disadvantages can be overcome. He said that "there are 138 legislators, but not all 138 matter. For those that matter, gender is not as big an issue." The female participant responses had variation. Two of the female legislators agreed that gender does affect a legislator's success, whereas one female legislator each said they strongly disagreed, disagreed, and neither disagreed or agreed. Participant F said, "The more power you accrue the more gender matters and is significant..." With more power, it means more attention and eyes on the lawmaker, which is significant especially when there are so few women. Participant G, who has a couple of decades of experience, said that there were negative aspects to being a female legislator, such as "you are expected to do women's issues...you may be tapped as a token woman on the committee... you have to work very hard, so that you are not discounted as a female." On the other side of the spectrum, Participant H said, "it doesn't matter. It's about work ethic, truth, and cooperation." Similarly, Participant I said, "Success is determined by what you do." Even more strongly, Participant J said, "I refuse to accept that as a factor in my success."

\section{POLICY PRIORITIES AND WOMEN'S ISSUES}

Next, the interview participants were asked about which of their policy priorities they considered, if any at all, "women's issues." Interestingly, none of the male participants were willing to definitively say that their policy priorities were only "women's issues," in the sense that policy areas affect both genders in some way. Participant A said that policy areas were "not necessarily gender specific issues, but do affect women." Participant B said, "None of my 3 policy areas I would consider as favoring one gender over another.” Participant $\mathrm{C}$ also said that 
his priorities were male or female issues. Participant D simply said, “They are all women's issues...they are people issues." Participant E said that none of the policy areas were "women's issues," but that "to say that does the issue a disservice and women..." He further elaborated by saying that issues disproportionately may affect one gender over another, but it is "best for everyone to understand how issues affect people." Female interview participants were more willing to name specific policy areas as "women's issues." Only one female participant said that there aren't women's issues, only people issues. The rest of the female interview participants either identified their priority areas as "women issues" or areas that effect men and women. WOMEN'S ISSUES FREQUENCY IN GENERAL ASSEMBLY

The last question asks about the frequency with which women's issues come up in a legislative session. A majority of the participants say that women's issues come up frequently. The 2 participants that did not say that women's issues occur frequently were both males in the House who either said occasionally or rarely. These 2 participants also did not view issues as necessarily divided by gender. As a result, their response could be accounting for not seeing issues divided as women or men issues.

\section{QUANTITATIVE SENATE DATA}

The qualitative data is an important connecting factor with the interview results because the interviews measured priorities and accomplishments with in-depth conversations, while the bill data provided a more concrete measure of priorities and accomplishments.

[Figure 2 here]

The Senate bill measurements are the result of analysis of 201 bills from the 2015 legislative session. Unsurprisingly, $85.57 \%$ of the primary sponsors of bills in the senate were male, whereas only $14.43 \%$ were sponsored by female legislators. Also, in the 2015 legislative 
session, only 36 bills from the Senate were signed by the governor, or $17.91 \%$ of the total bills. For comparison, 119 died in committee (59.20\%) and 46 made it to the House $(22.89 \%)$. Interestingly, of the bills that were signed by the governor that came from the Senate, only 6 were bills that had a female as the primary sponsor.

[Figure 3 here]

For all of the Senate bills with a female primary sponsor, most of the bills failed in committee or in the House, and the 6 bills that were signed by the governor made up 20.69\% of the bills with women as primary sponsors. Males seemed to have slightly less success when it comes to getting bills to the desk of the governor. $17.44 \%$ of the Senate bills with a male as primary sponsor were signed by the governor, while the majority either failed in committee or failed in the House.

[Figure 4 here]

In the Senate, there are 2 Republican and 2 Democrat women. However, there were only $11(37.93 \%)$ bills that had Democrat women as primary sponsors, whereas $18(62.07 \%)$ of the bills were sponsored by Republican women. In the Senate, the Republicans hold the majority, so male Republicans outnumber male Democrats. $41(24.7 \%)$ of the male primary sponsors were Democrats and $125(75.3 \%)$ of the male primary sponsors were Republicans. Democrat women represents $50 \%$ of women in the Senate and Republican women represents the other $50 \%$. The percentage of bills sponsored by female primary sponsors is not proportional to the number of women by party in the Senate, which could be because Republicans are the majority in the Senate.

[Figure 5 here] 
The bills were not coded by policy areas to measure gender difference. However, measuring gender differences in committee assignment was important to have a barometer of the bill issue areas. The bills with women as primary sponsors were diverse in committee assignments for the 2015 legislative session. The committee assignments for bills with males as primary sponsors are diverse as well. Yet, women were not the primary sponsor on any bills assigned to the Appropriations and Revenue, Banking and Insurance, Economic Development, or the Transportation committees. In both Figure 6 and Figure 7, the top areas were bills were assigned for both genders were Judiciary and State and Local Government. This could be reflective that for the 2015 legislative session those committees received the most legislative attention.

[Figure 6 here]

[Figure 7 here]

\section{QUANTITATIVE HOUSE DATA}

The data from the House is the result of 526 bills from the 2015 legislative session. Similarly to the Senate, $77.95 \%$ of the primary sponsors of bills were male, whereas only $22.05 \%$ were sponsored by female legislators. Next, in the 2015 legislative session, $15.40 \%$ of the House bills were signed by the governor. Most of the bills either failed in committee or in the Senate. $69.01 \%$ of the bills failed in committee or 363 bills, whereas $15.59 \%$ of the bills failed in the Senate, or 82 bills. Finally, out of the bills that were signed by the governor, only 14 were bills that had a female as the primary sponsor.

[Figure 8 here]

For all of the House bills with a female primary sponsor, 85 of the bills failed in committee (73.28\%), 17 of the bills (14.66\%) failed in the Senate, and $14(12.07 \%)$ of the bills 
were signed by the governor. Males had similar success results. 278 of the bills that had a male as a primary sponsor failed in committee $(67.80 \%), 65$ of the bills failed in the Senate $(15.85 \%)$, and 67 of the bills were signed by the governor (16.34\%). It is noteworthy to point out that male primary sponsors had slightly more success than female primary sponsors in having their bills signed by the governor.

[Figure 9 here]

[Figure 10 here]

In the Senate, there are 8 Republican and 11 Democrat women. Democrats hold the majority in the House of Representatives. As a result, it is not surprising that $83(72.17 \%)$ of the primary sponsors were Democrat women, whereas $32(27.83 \%)$ of the bills were sponsored by Republican women. Moreover, $282(68.95 \%)$ of the primary sponsors were Democrat males and 127 (31.05\%) of the primary sponsor were Republican women.

[Figure 11 here]

The bills with women as primary sponsors were placed in a variety of committees. It is interesting to note that the Education and the Judiciary committees received a significant portion of the women primary sponsor committee assignments. The committee assignments for bills with males as primary sponsors also had variety, with the Judiciary and Appropriations committee receiving a significant portion of their bills.

[Figure 12 here]

[Figure 13 here]

\section{LIMITATIONS}

One limitation of the study was that it was difficult to make generalizations from the interview data because there were only 10 participants. While an equal number of men and 
women participated in the study, the interviews lacked balance in party, geographic region, and chamber. Additionally, it made statistical analysis difficult because the sample size was not large. Generalizations are certainly easier if the sample size is larger or representative of the population. Also, the participants who agreed to in-person interviews resulted in more in-depth responses. The participants who agreed to phone interviews still provided in-depth responses, but since it was not face-to-face, the engagement was different partly because nonverbal communication is missing from phone interviews. The one representative who sent me a written response provided straight-forward, simple responses. It seems to be due to there being no engagement with me as an interviewer.

Another limitation in my quantitative data was that it was data drawn only from the 2015 legislative session, due to time and labor constraints. The Legislative Research Commission does not maintain the data that I was researching, so I had to pull the information from each individual bill from the 2015 legislative session. In the 2015 session, there were over 700 bills, not including resolutions. Another concern with pulling data from the 2015 legislative session was that it was a short session. In the state of Kentucky, odd numbered years are short sessions and even numbered years are long sessions. However, only in the long legislative session is the budget reviewed.

\section{CONCLUSION}

This research was conducted to investigate if there was a gender difference in the legislative priorities and perceptions of success among Kentucky legislators. In order to investigate this question, I had three hypotheses: One, the legislative priorities of Kentucky women legislators will be similar to Kentucky male legislators because of constituency constraints. Next, there will not be uniformity in how and if legislators classify their legislative 
priorities as "women's issues." Finally, male legislators will be more likely to attribute success to themselves and women will be more likely to attribute success to collaboration efforts that involve others.

In regards to my hypothesis that the legislative priorities of Kentucky women legislators will be similar to Kentucky male legislators because of constituency constraints, the data showed it to be partially supported. Women legislators gave responses that included some policy areas that were similar to men, but not all. However, the overall reasoning behind this does not seem due to constituency constraints. In both the responses as to why legislators felt comfortable handling certain areas and why their policy priorities were the policy priorities, responses dealing with constituency constraints were never elicited. The quantitative data on committee assignments of bills in the Senate by the gender of the primary sponsor may reflect support of $\mathrm{H} 1$ as well because Senate bills were assigned to a variety of committees regardless of the primary sponsor gender.

My next hypothesis was that there would not be uniformity in how and if legislators classify their legislative priorities as women's issues. However, based on the interviews, there was uniformity in what legislators classify as women issues, in the fact that the legislators as a whole seemed to agree that issues affect both genders in different ways and there is difficulty in identifying issues as women's issues. In the fact, 8 out of 10 of the legislators agree that women's issues come up when the general assembly is in session. As one legislator put said, “women's issues come up about as often as men's issues." The view of women's issues ties into how the legislators view gender and success over all because how an individual views the impact of their on gender could impact how and why they may think certain issues are (or are not) women's issues. Men generally did not think gender impacts a legislators success, where at least 
some of the women participates thought it does. Thinking along those lines could impact how legislators prioritize their policy priorities and their actions and pursuit of success in the legislative action.

Moreover, women more easily identified policy areas as women's issues, which leads back to descriptive representation. If women are expected to represent women, then it may be easier to identify policy priorities as women's issues because the legislator either is expected to pursue those issues by colleagues, constituents, or even themselves. For men, it could be more difficult because men representing women's issues are not an expectation. In my interviews is was only women who said or alluded to being the token woman on an issue or committee, or being pigeon hold into an issue by male colleagues.

Another significant difference was that women rated professional experience in contributing to success as a legislator a little more important than men did. However, in the interviews both men and women spoke the experience in its influence on their policy priorities, which could indicate why the rating of the importance of professional experience is not too far from men.

My last hypothesis was that male legislators would be more likely to attribute success to themselves and women would be more likely to attribute success to collaboration efforts that involve others. This hypothesis was not supported. While male legislators were more likely to cite specific, tangible actions in their definition of success, both men and women highly ranked the importance of personal initiative. At the same time, both men and women legislators attributed collaboration to their success as a legislator.

There are some revisions to the study that should be made in the future. First, there would need to be some changes in the interview process. First, the interviews worked best when 
conducted in-person, so, all of the interviews should be conducted in-person in the future. It seemed when legislators could speak with me in-person the responses had more depth.

Also, it may be worth considering changing or attempting to see the success of conducting interviews that were audio recorded. The interviews were not recorded in order to decrease the interview participation risk for the interview subjects. While having anonymously reported interviews that were not recorded assisted in garnering interview participants, audio recorded interviews would have allowed for exact records of the responses. This, therefore, could have made the data more precise. Also, written interview notes can cause one to disconnect with the interviewee because the focus is on recording the information quickly and accurately, rather than connecting with the interviewee to elicit in-depth responses.

Next, there are a few interview questions that should be changed. In the interview section on legislative priorities, the first two questions about the policy areas the legislators felt most knowledgeable about and comfortable handling and the question of their three most important priorities need to be combined. While sometimes the question elicited different responses from legislators, more often than not, the questions elicited same answers. Some legislators actually responded with same as the previous question or even just said the same answers as the first question.

Additionally, a second question under the legislative perception of success section on the interview needs to be added. I am sure there are other areas that contribute to success that I did not measure. However, it was important to ask specifically about a few areas just in case the legislator would simply forget to mention certain areas they think could contribute to success. While there are many improvements that could be made for this project, the thesis as is has many implications. First, measuring for gender differences in self-perception of success 
could be a significant tool to examine the quantitative research on success. While bill passage rates may demonstrate that men are more success than women as legislators, if making the community a better place is a sign of success for women rather than the number of bills they pass that could change the importance of the bill passage data that is focused on so heavily. The selfperception concept can add to the literature in answering the question "are women legislators as successful as men?" The difference in the success of legislators by gender could exist because men and women see success differently and as a result their legislative behavior mirrors their thought process on success.

Next, these results could be generalizable to states that also rank similarly for the number of women in its state legislature. The potential for research to be done across states is an opportunity to learn if there are differences and what is the contrast in states with more women in their state legislature versus states with fewer women. Furthermore, comparing higher ranked states for women in state legislature with lower ranked states could mean two things: having a critical mass could impact policy priorities and what success means, and that if a critical mass is needed then political ambition in women needs to be overcome to get more women in office to achieve that critical mass.

The number of female legislators can affect how a woman is treated as far as what policy areas is expected for the legislator to handle and even just proving they belong as was evident from the interviews in this thesis. This could be concerning especially when representatives like U.S. Senator Susan Collins say, "When women are elected to the Senate, I think they still have to prove that they belong there... Once they get through some initial test, then they're accepted and they're a member of the club. Men don't face that barrier. It is assumed that if a male is elected to the Senate, that he belongs there" (Levitz, Jennifer 2016). It is reasonable to expect that when 
an institution like Congress is male-dominated, a Congresswoman could feel this way. Research on gender differences in policy priorities and success give us insight into how and why overcoming political ambition gaps and increasing the number of female legislators matter. All in all to really leverage an understanding of the impact of having a low number of elected female issues a focus on policy priorities and self-perception of success can assist in that aspect.

Finally, while the interviews in this research did not find a gender difference in the importance of collaboration (both men and women said collaboration was important), literature demonstrates that collaboration is an important to for an underrepresented group such as women to gain power and influence as lawmakers (Barnes 2016, p. 316). Perhaps this thesis could be taken a step further by measuring why collaboration is important for Kentucky lawmakers, particularly women. Barnes believes that collaboration is key for minorities like women to obtain power and influence (Barnes 2016). There is a key example of this in the U.S. Senate in 2013. The New York Times shared the story of three female Senators who led the way on reaching across the aisle to a compromise to end a government shutdown. Senator Collins said, "I don't think it's a coincidence that women were so heavily involved in trying to end this stalemate...Although we span the ideological spectrum, we are used to working together in a collaborative way" (Weisman and Steinhauer 2013). These women used collaboration efforts to influence steps toward ending a government shutdown. Furthermore, demonstrating that this situation is just one insistence of demonstrating how collaboration can be used as an important tool for women.

\section{FURTHER RESEARCH}

This research opens up another area of questions about the priorities and perceptions of success of minority members, particularly African American members in the Kentucky state 
legislature. There are even fewer African American members of the Kentucky legislature than there are women. Furthermore, this could lend itself to the question as to why there are so few minorities in the state legislature.

On a regional level, this thesis could be expanded to compare other conservative states in the south to examine any differences in the priorities and perceptions of success of legislators. This also could be used as a starting point to compare regions of the country to one another on legislative priorities and perceptions of success.

Finally, on a national level, measuring self-perception of success on the Congressional level would be useful comparison tool for the state level. While it may harder to interview members of Congress, the research does leave open how gender differences in self-perception in state level legislators would compare to members of Congress. 


\section{WORKS CITED}

Barnes, Tiffany. (2016). Gendering Legislative Behavior: Institutional Constraints and Collaboration. Cambridge.

Barrett, Edith. (1995). “The Policy Priorities of African American Women in State Legislatures.” Legislative Studies Quarterly 20(2): 223-247. http://www.jstor.org/stable/440449

Beckwith, Karen and Cowell-Meyers. (2007). "Sheer Numbers: Critical Representation Thresholds and Women's Political Representation.” Perspectives on Politics 5(3): 553565. http://www.jstor.org/stable/20446503

Bratton, K. A. (2002). Critical Mass Theory Revisited: The Behavior and Success of Token Individuals in State Legislatures. Conference Papers -- American Political Science Association, 1-31.

Bratton, K. A., \& Haynie, K. L.. (1999). Agenda Setting and Legislative Success in State Legislatures: The Effects of Gender and Race. The Journal of Politics, 61(3), 658-679. Retrieved from http://www.jstor.org/stable/2647822

Cammisa, Anne Marie, \& Reingold, Beth. 2004. "Women in State Legislatures and State Legislative Research: Beyond Sameness and Difference." State Politics \& Policy Quarterly 4(2): 181-210. http://www.jstor.org/stable/40421515

Center for American Women and Politics (CAWP). (2015). Eagleton Institute of Politics at Rutgers, The State University of New Jersey: New Brunswick, NJ.

Clark, Jennifer, \& Caro, Veronica. (2013). "Multimember Districts and the Substantive Representation of Women: An Analysis of Legislative Cosponsorship Networks.” Politics \& Gender. 1-30. 
Davidson, R., Oleszek F., Lee, F., \& Schickler E. (2014). Congress and It's Members. California: CQ Press.

Ellickson, M. C. (1992). Pathways to Legislative Success: A Path Analytic Study of the Missouri House of Representatives. Legislative Studies Quarterly, 17(2), 285-302. Retrieved from http://www.jstor.org/stable/440062

Fenno, Richard F. (1978). Home Style: House Members in Their Districts. HaperCollinsPublishers.

Gainous, Jason. "An Introduction to Statistical Computing for the Social Sciences Using R" Hogan, Robert. (2008). "Sex and the Statehouse: The Effects of Gender on Legislative Roll-Call Voting." Social Science Quarterly 89(4): 955-968.

Jeydel, Alana, \& Taylor, Andrew. (2003). “Are Women Legislators Less Effective? Evidence from the U.S. House in the $103^{\text {rd }}-105^{\text {th }}$ Congress." Political Research Quarterly 56(1): 19-27. www.jstor.org/stable/3219880

Levitz, Jennifer. (2016). Susan Collins Says Women in Politics Still Face Barriers. Wall Street Journal. Retrieved from http://blogs.wsj.com/washwire/2016/03/07/susan-collins-sayswomen-in-politics-still-face-barriers/.

Little, T. H., Dunn, D., \& Deen, R. E. (2001). A View from the Top: Gender Differences in Legislative Priorities Among State Legislative Leaders. Women \& Politics, 22(4), 29.

Mansbridge, Jane. (1999). "Should Blacks Represent Blacks and Women Represent Women? A Contingent 'Yes."' Journal of Politics 63 (3): 627-657.

Mansbridge, J. (2005). Quota problems: Combating the dangers of essentialism. Politics \& Gender, 1(4), 622-638. Retrieved from http://search.proquest.com/docview/194688315?accountid=14665 
Mosley, L. (2013). Interview research in political science. Ithaca: Cornell University Press.

Newport, F. (2015). Mississippi, Alabama and Louisiana Most Conservative States. Retrieved February 27, 2016, from http://www.gallup.com/poll/181505/mississippi-alabamalouisiana-conservative-states.aspx

"Physiographic - Kentucky Atlas and Gazetteer." Physiographic - Kentucky Atlas and Gazetteer. http://www.kyatlas.com/kentucky-atlasp.html.

Pitkin, Hanna F. The Concept of Representation. Berkeley: University of California Press, 1972. Poggione, Sarah. (2004). “Exploring Gender Difference in State Legislators’ Policy Preferences.” Political Research Quarterly 57(2): 305-314. http://www.jstor.org/stable/321987

Rubin, Herbert and Rubin, Irene. (2005). Qualitative Interviewing: The Art of Hearing Data. Thousand Oaks, California: Sage Publications.

Smooth, Wendy. (2011). "Standing for Women? Which Women? The Substantive Representation of Women's Interests and the Research Imperative of Intersectionality." Politics and Gender 7(3): 436-441.

Swers, Michele.(2001). "Understanding the Policy Impact of Electing Women: Evidence from Research on Congress and State Legislatures." Political Science and Politics 34(2): 217220. http://www.jstor.org/stable/1350206

Swers, Michele. (2005). "Connecting Descriptive and Substantive Representation: An Analysis of Sex Differences in Cosponsorship Activity." Legislative Studies Quarterly 30(3): 407433. http://www.jstor.org/stable/3598642 
Thomas, Sue. (1991). "The Impact of Women on State Legislative Policies." The Journal of Politics 53(4): 958-976. www.jstor.org/stable/2131862

Thomas, Sue \& Welch, Susan. (1991). "The Impact of Gender on Activities and Priorities of State Legislators." The Western Political Quarterly 44(2): 445-456. http://www.jstor.org/stable/448788

Thomas, Sue. (2005). Women and Elective Office Past, Present, and Future. 2nd ed. New York: Oxford University Press.

Volden, C., Wiseman, A. E., \& Wittmer, D. E. (2013). When Are Women More Effective Lawmakers Than Men?. American Journal of Political Science, 57(2), 326-341. Retrieved from http://www.jstor.org/stable/23496600

Volden, Craig, Wiseman, Alan, \& Wittmer, Dana. (2013).”Women's Issues and Their Fate in Congress" (Working paper 7-2013). Retrieved from Vanderbilt University website: http://www.vanderbilt.edu/csdi/research/CSDI WP 07-2013.pdf

Weisman, Jonathan and Steinhauer, Jennifer. (2013). "Senate Women Lead in Effort to Find Accord." New York Times. Retrieved from http://www.nytimes.com/2013/10/15/us/senate-women-lead-in-effort-to-findaccord.html? $\mathrm{r}=0$. 
Figure 1

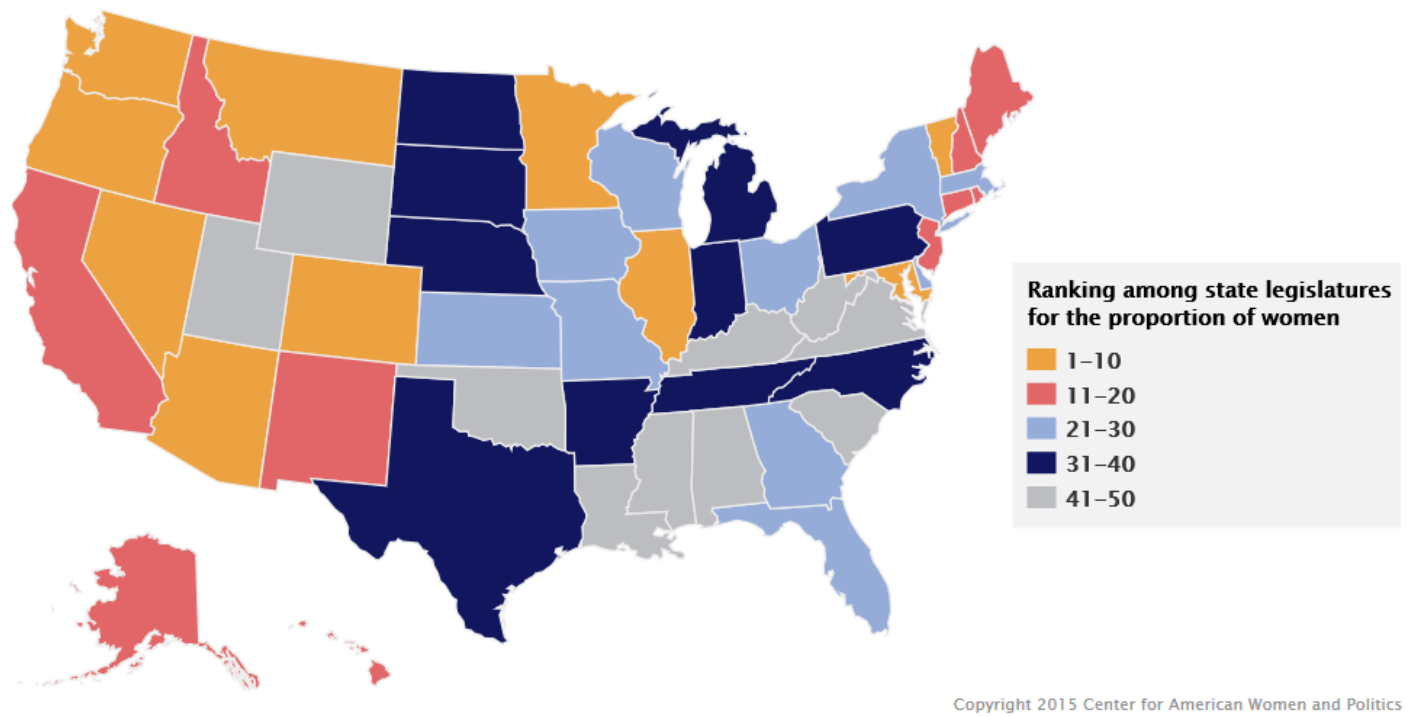

*Center for American Women and Politics 2015 Data on Women in State Legislatures 
Allen 46

Figure 2

\section{Senate Bill Primary Sponor Gender Percentage}

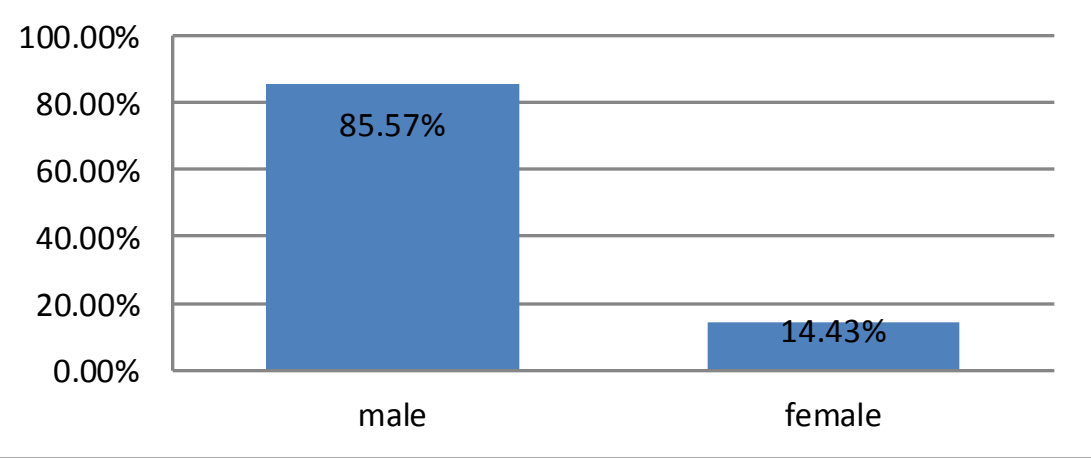


Figure 3

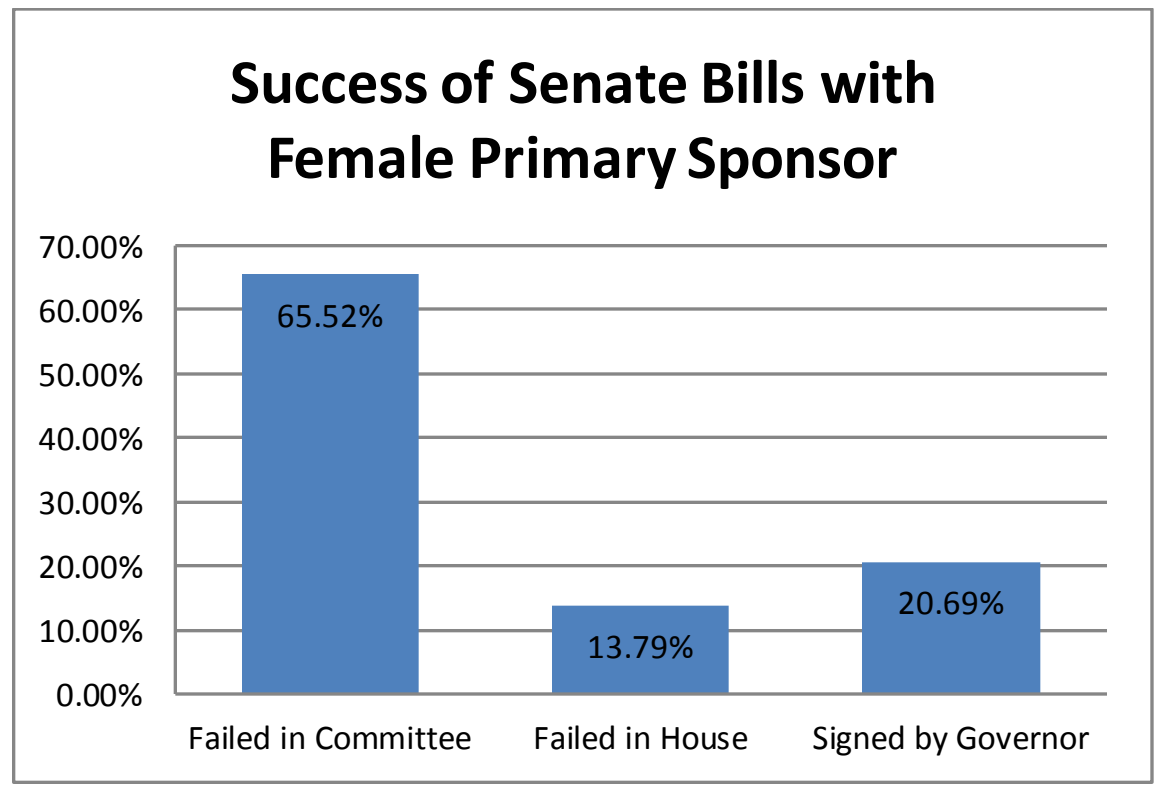


Figure 4

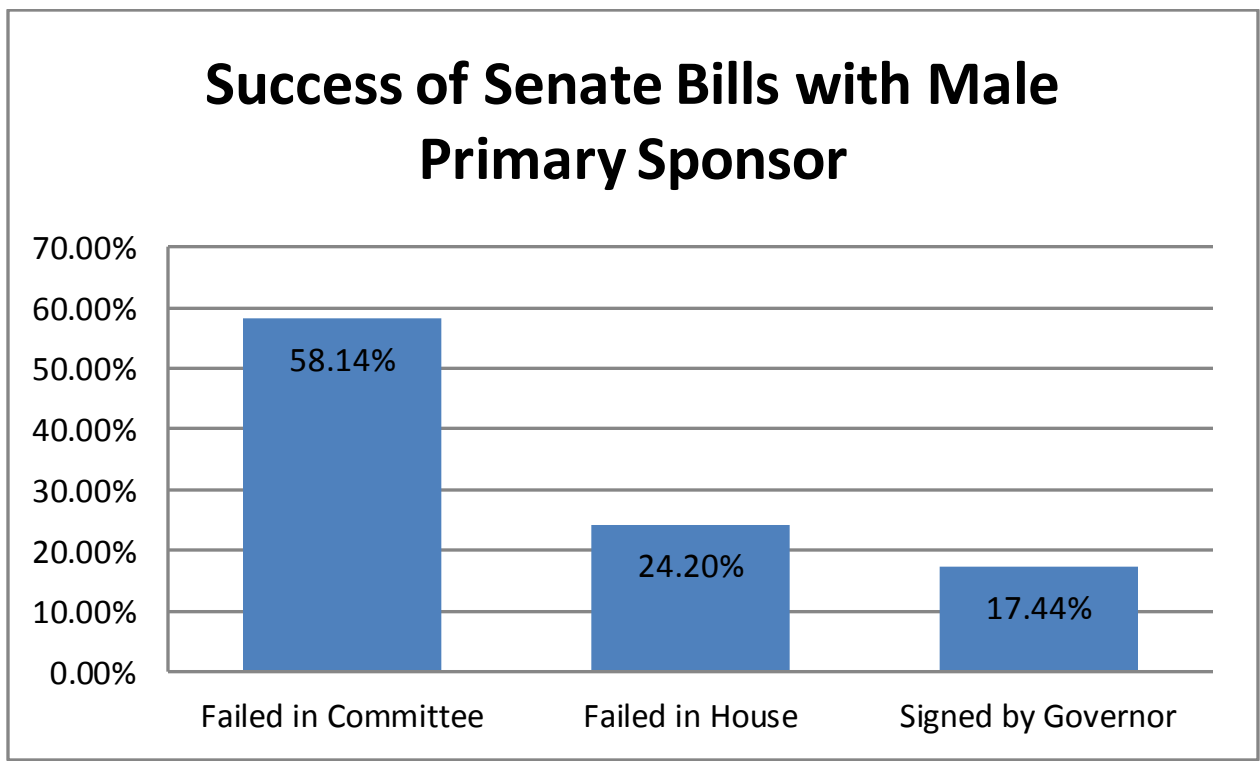


Figure 5

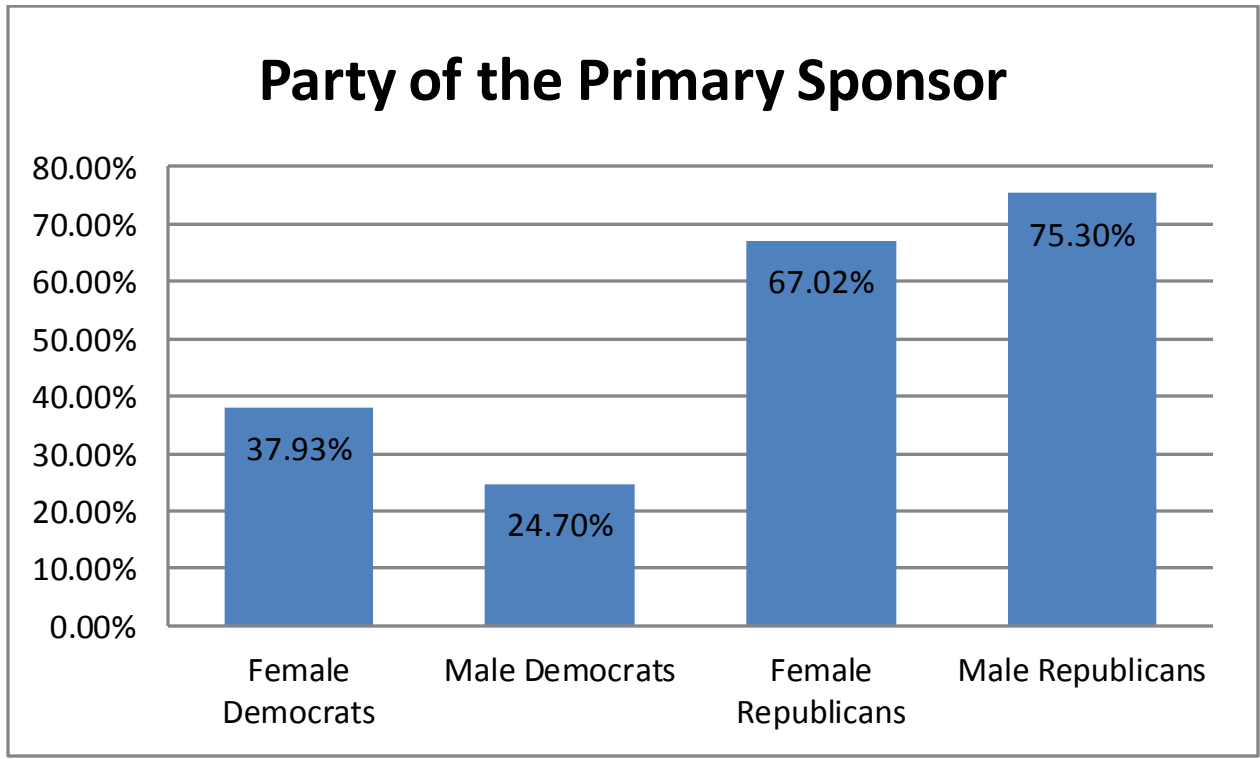


Figure 6

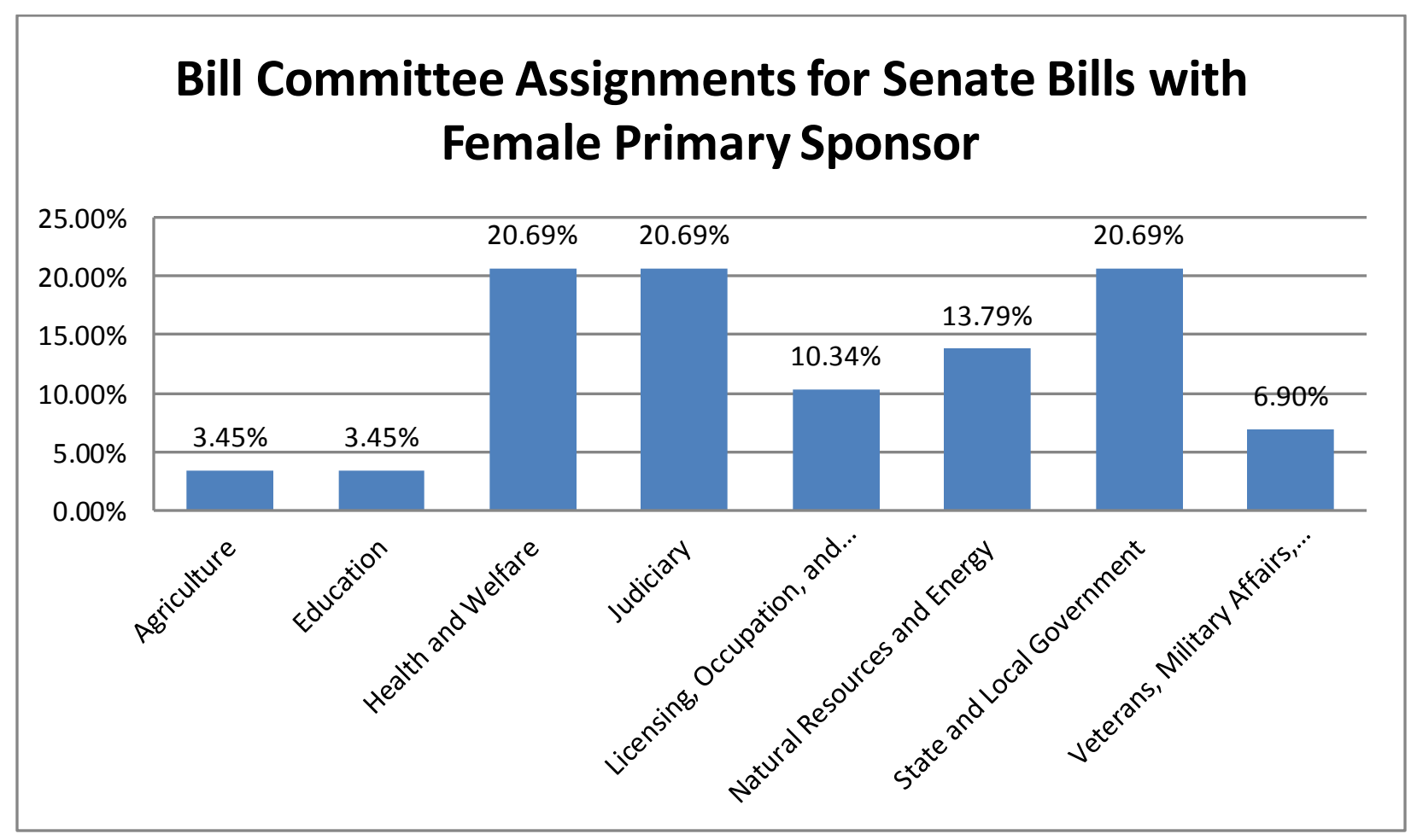


Figure 7

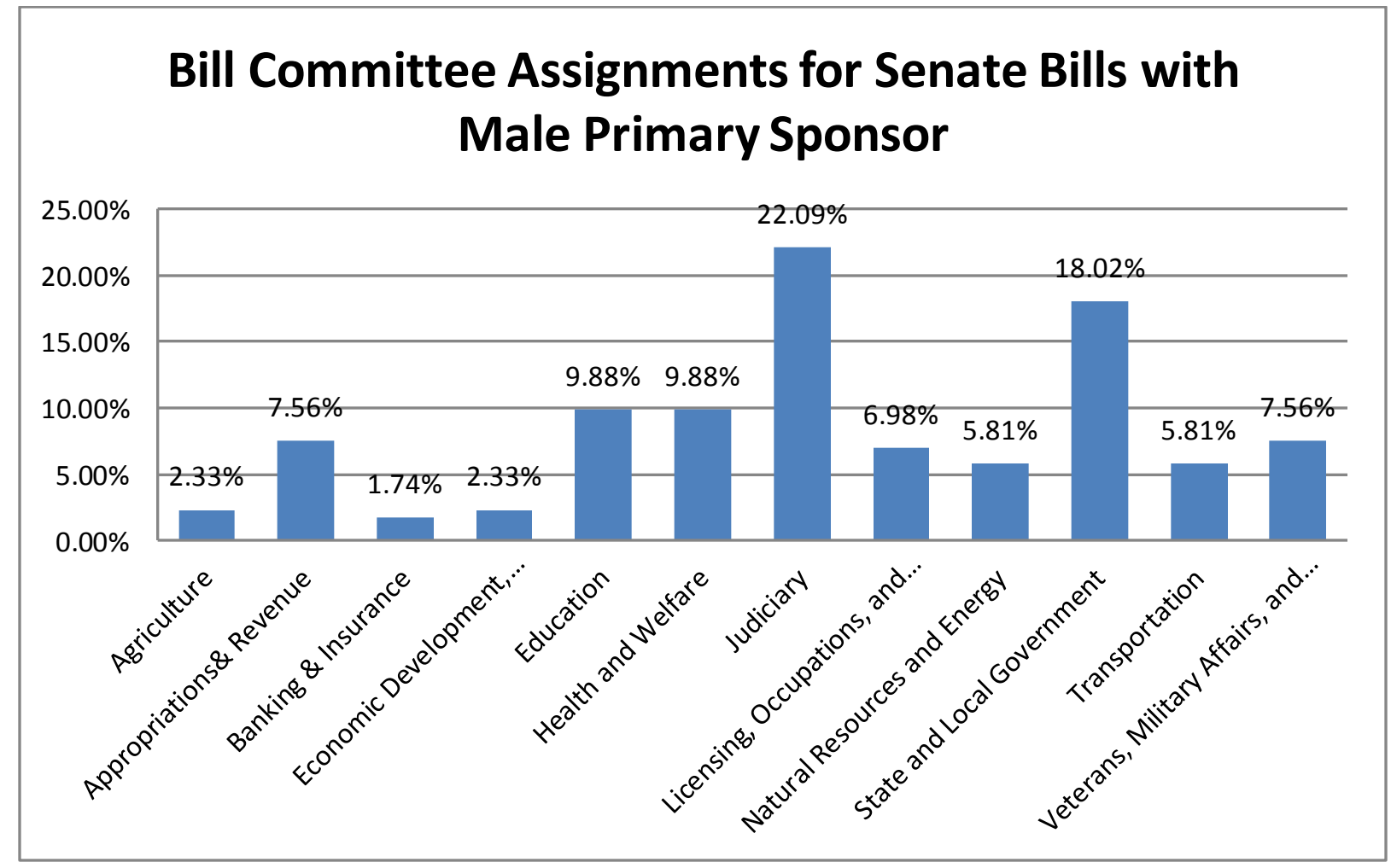


Figure 8

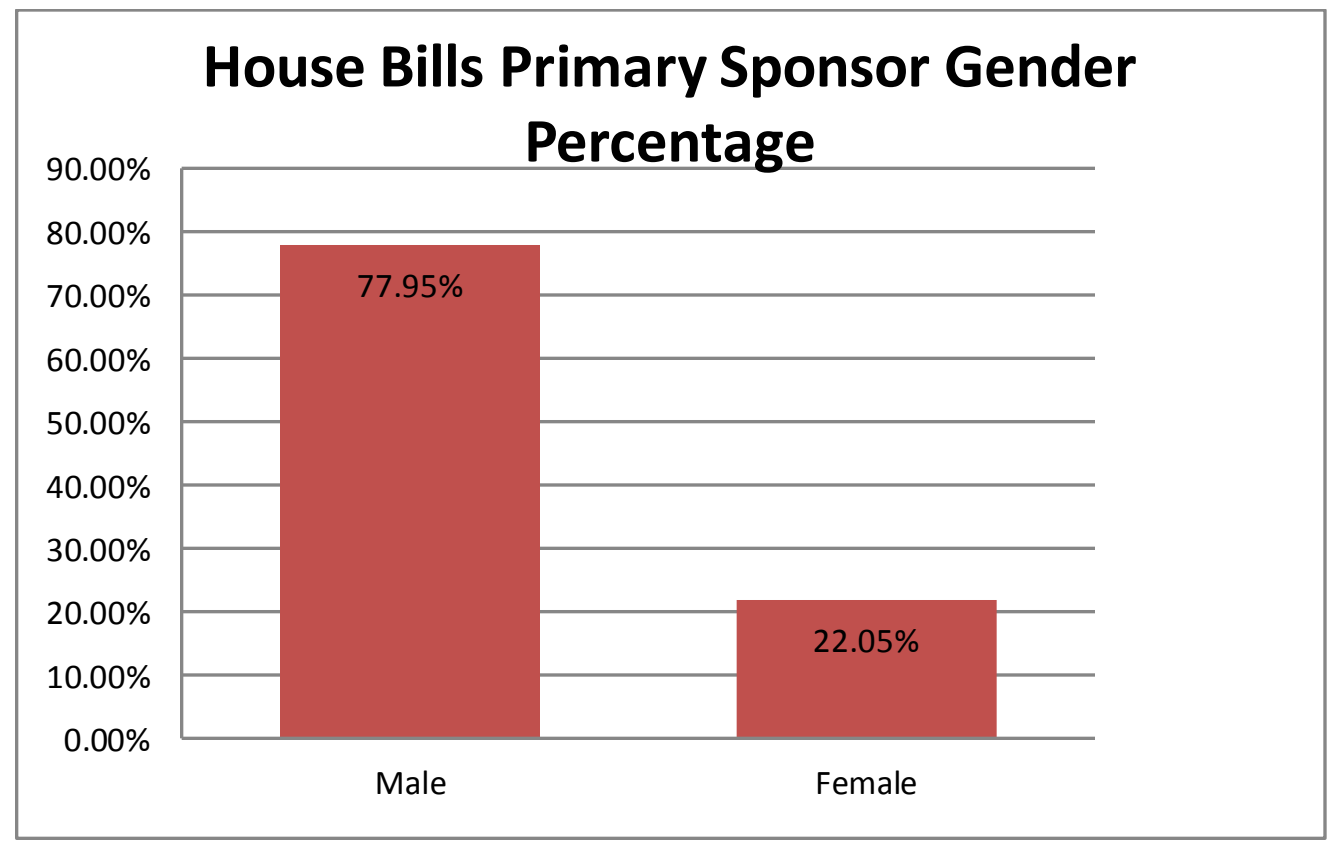


Figure 9

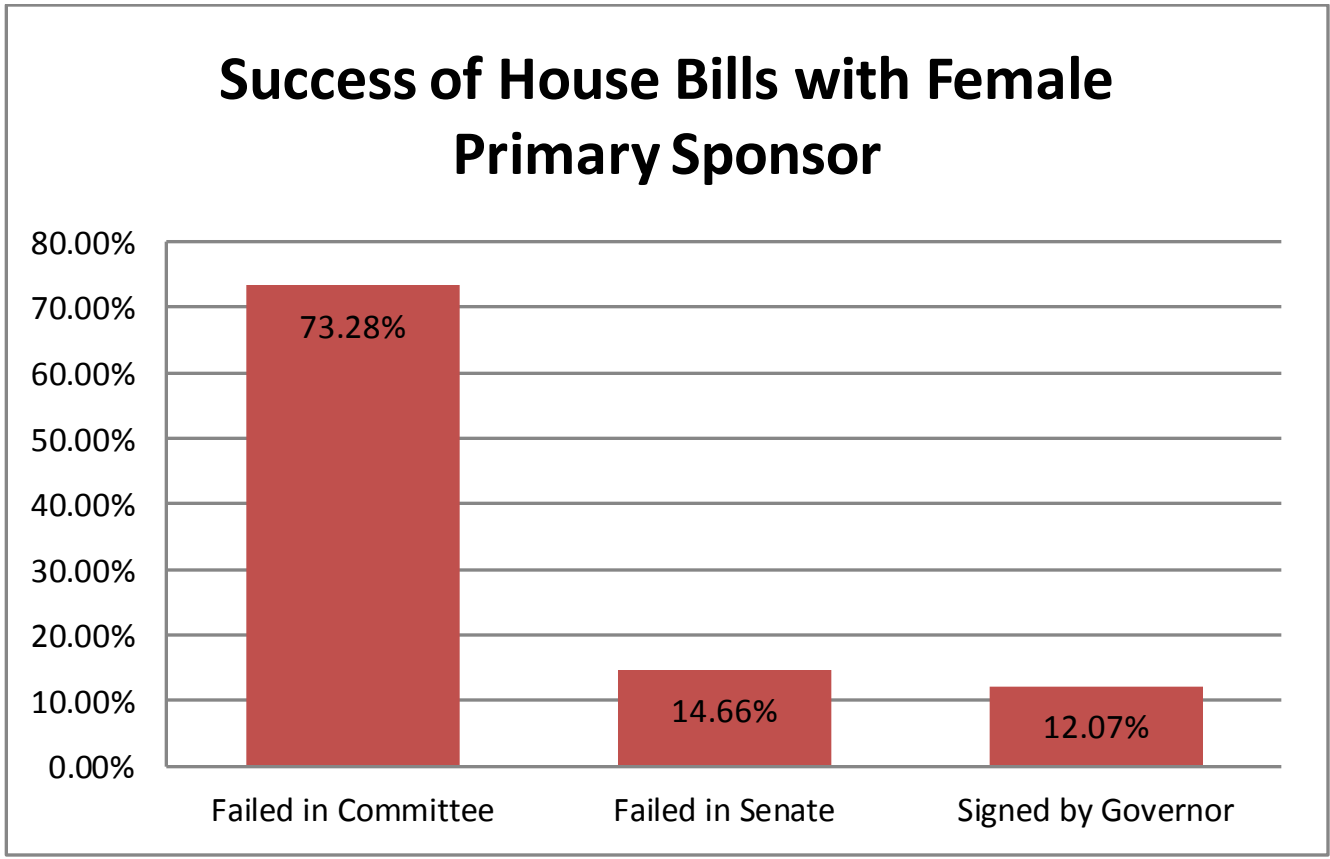


Allen 54

Figure 10

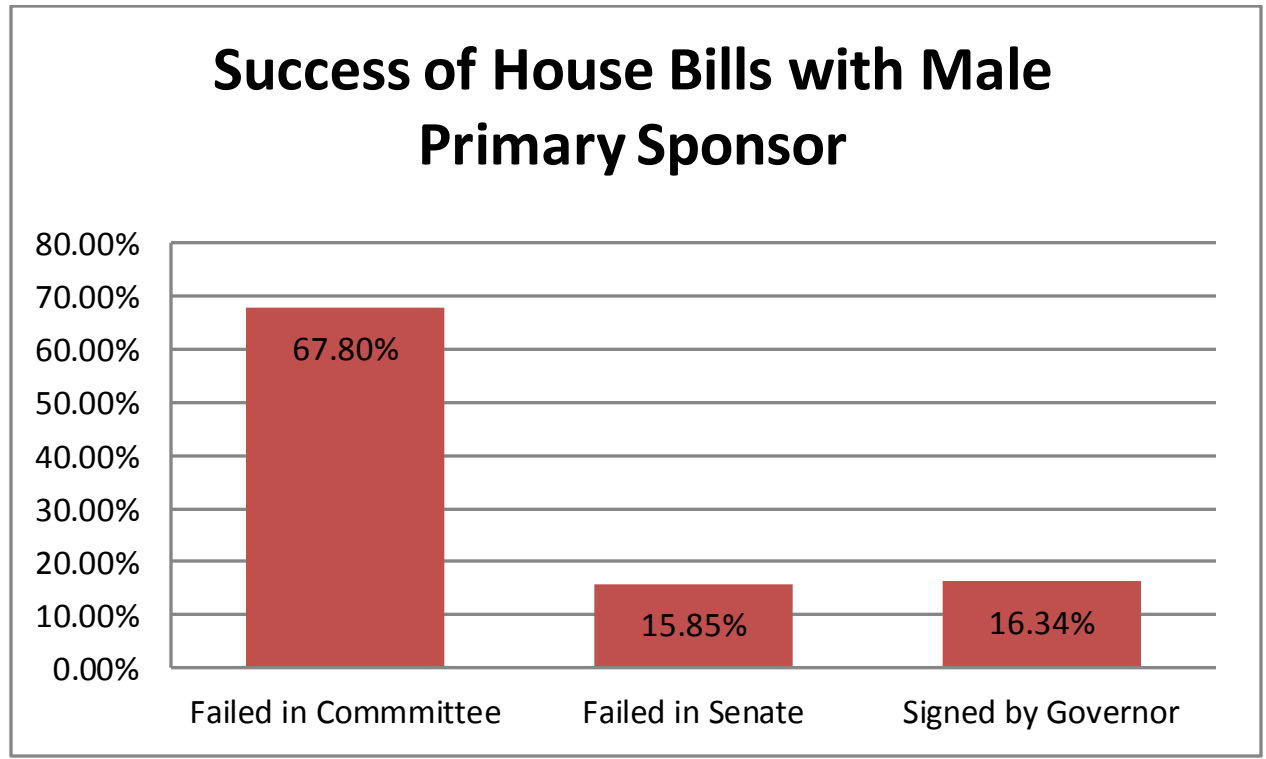


Allen 55

Figure 11

\section{Party of Primary Sponsor (House)}

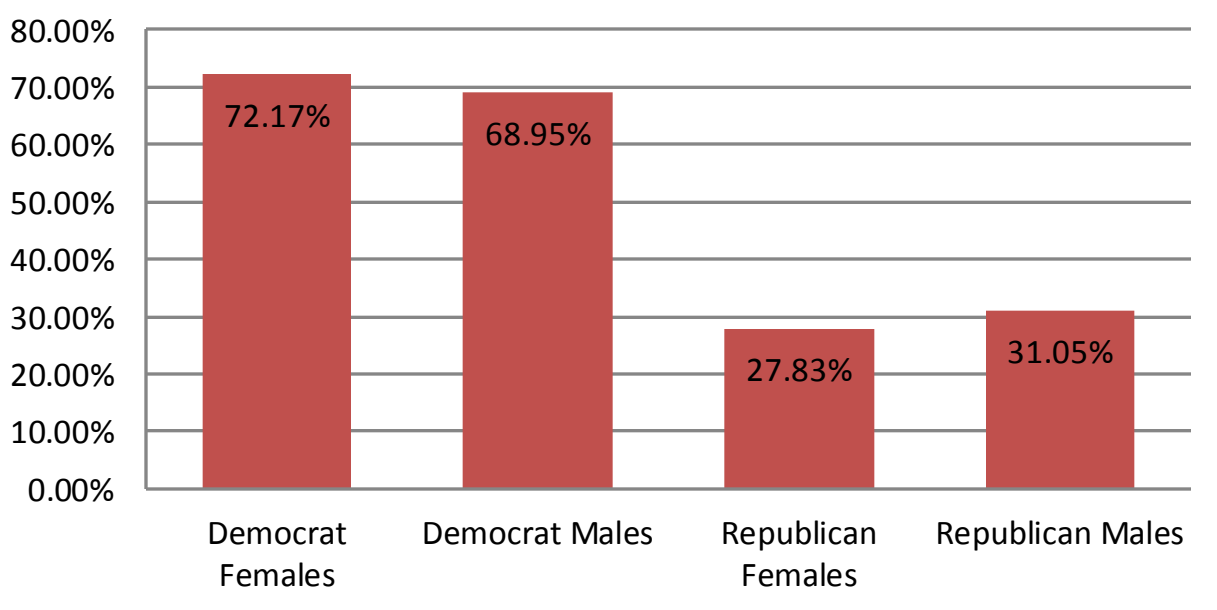


Figure 12

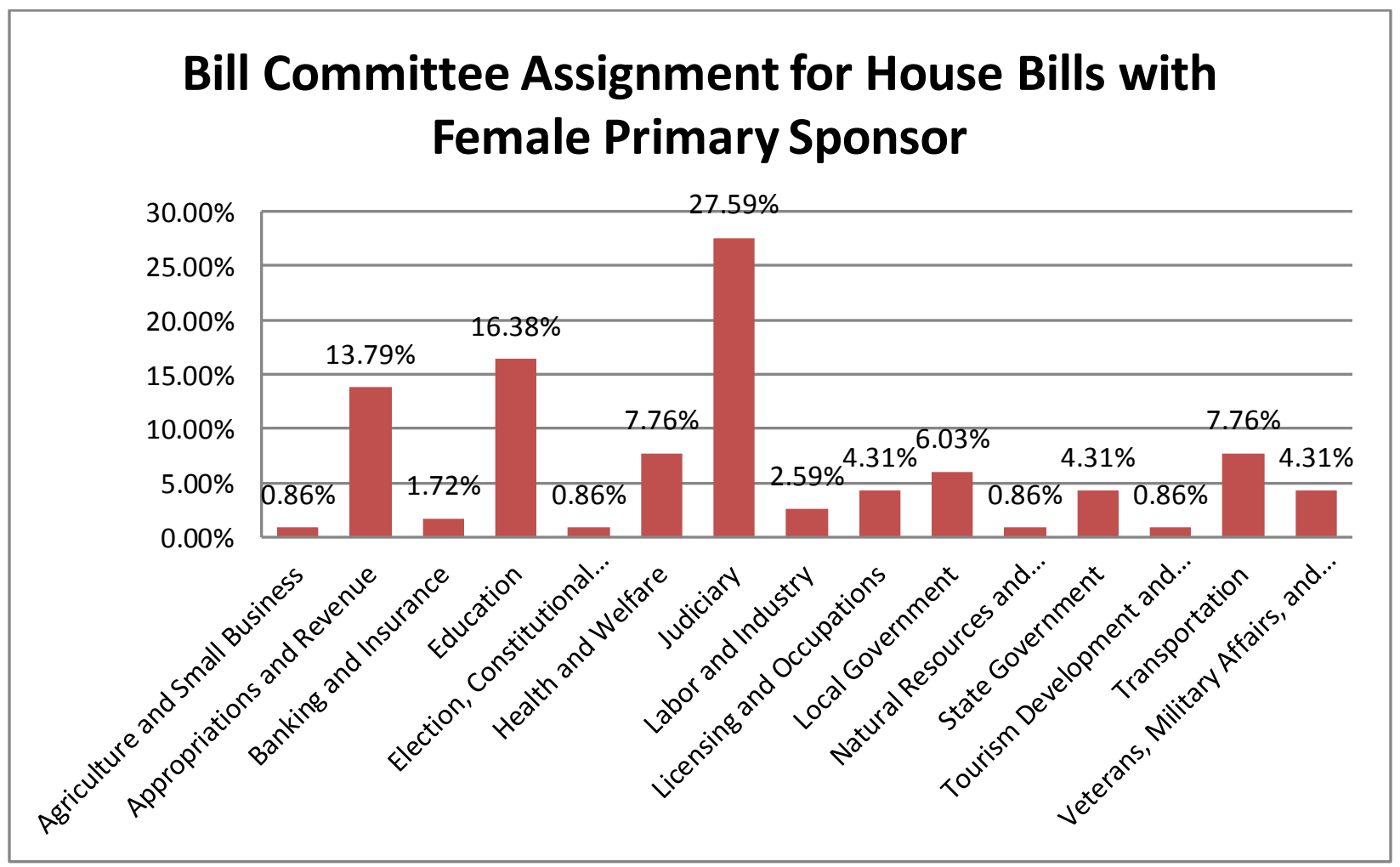


Figure 13

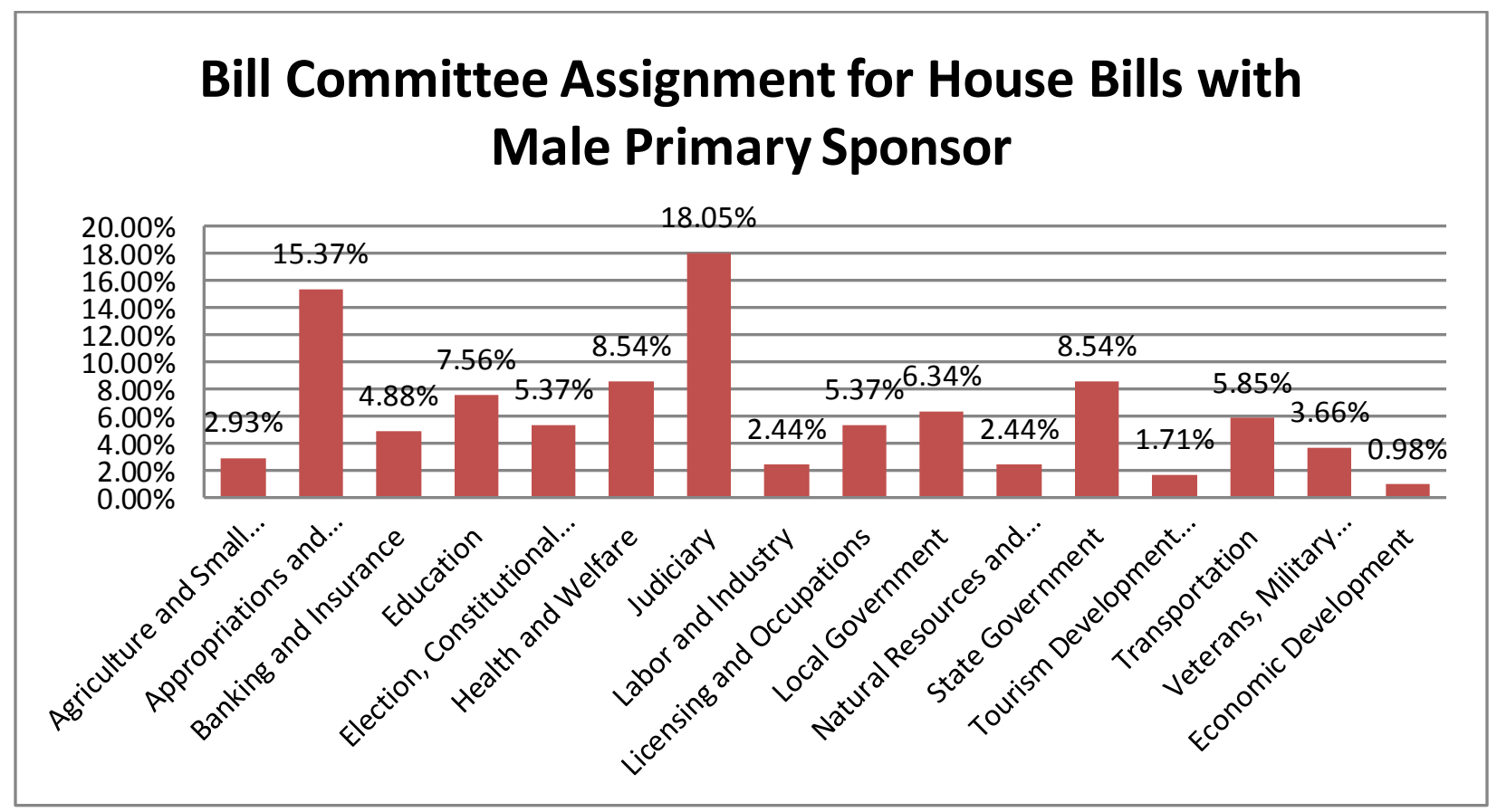


Table 1

\begin{tabular}{|c|c|c|c|c|c|c|c|c|c|c|}
\hline \multirow[t]{7}{*}{ Region } & \multicolumn{10}{|c|}{ Gender } \\
\hline & \multicolumn{5}{|c|}{ Male } & \multicolumn{5}{|c|}{ Female } \\
\hline & \multicolumn{5}{|c|}{ Chamber } & \multicolumn{5}{|c|}{ Chamber } \\
\hline & \multicolumn{5}{|c|}{ Party } & \multicolumn{5}{|c|}{ Party } \\
\hline & & \multicolumn{2}{|c|}{ Democrat } & \multicolumn{2}{|c|}{ Republican } & & \multicolumn{2}{|c|}{ Democrat } & \multicolumn{2}{|c|}{ Republican } \\
\hline & Total & House & Senate & House & Senate & Total & House & Senate & House & Senate \\
\hline & 5 & 1 & 1 & 1 & 2 & 5 & 4 & 1 & 0 & 0 \\
\hline $\begin{array}{l}\text { Cumberland } \\
\text { Plateau }\end{array}$ & 0 & 0 & 0 & 0 & 0 & 1 & 1 & 0 & 0 & 0 \\
\hline $\begin{array}{l}\text { Bluegrass } \\
\text { Region }\end{array}$ & 3 & 1 & 1 & 1 & 0 & 4 & 3 & 1 & 0 & 0 \\
\hline $\begin{array}{l}\text { Pennyroyal } \\
\text { Region }\end{array}$ & 2 & 0 & 0 & 0 & 2 & 0 & 0 & 0 & 0 & 0 \\
\hline $\begin{array}{l}\text { Western } \\
\text { Coal Field }\end{array}$ & 0 & 0 & 0 & 0 & 0 & 0 & 0 & 0 & 0 & 0 \\
\hline $\begin{array}{l}\text { Jackson } \\
\text { Purchase } \\
\text { Region }\end{array}$ & 0 & 0 & 0 & 0 & 0 & 0 & 0 & 0 & 0 & 0 \\
\hline
\end{tabular}

*participant makeup 
Table 2

\begin{tabular}{|c|c|c|c|c|c|c|c|}
\hline Perceptions & Personal & Past & Professional & Support & Collaboration & Collaboration & Collaboration \\
of Success & Initiative & Experience & Experience & from Staff & with Fellow & with fellow & with fellow \\
& & Legislator & Legislator & & on & party & lawmakers \\
lawmakers in \\
the opposing \\
Tabulation \\
P-Value
\end{tabular}

* Statistical Significance Results of Likert Scale Measuring Legislative Success 
Table 3

\begin{tabular}{|c|c|c|}
\hline Gender and Success & Gender Affects a Legislators Success? & Frequency Women's Issues Come Up \\
in General Assembly \\
\hline Cross Tabulation P-Value & 0.39 & 0.29 \\
\hline Difference in Mean Test P-Value & 0.26 & 0.21 \\
\hline
\end{tabular}

* Statistical significance results of Likert scale measuring gender and success 


\section{APPENDIX A}

Date:

Dear

I am a student at the University of Louisville and am writing to request an interview as part of a research project for my undergraduate senior honors thesis. The goal of my project is to research the role of gender in legislative priorities and success. My goal is to speak with Kentucky state legislators, both men and women, to assist in answering this question.

Specifically, I am interested in our state legislators' policy priorities and how they perceive success in those priority areas. As you are a member of the Kentucky State Legislature, I would be honored to hear your thoughts on what legislative success means to you and your own legislative priorities including your perceptions. If you are able and willing to take part in this project, I would arrange an interview at your convenience at a public or private location of your choice. If feasible, we can talk in person. Other options include telephone, email, or Skype. Either way, I anticipate the interview would take about an hour of your time.

If you agreed to participate in this study, I would ask you to answer as many of the open-ended questions as you are comfortable doing. Of course, you may answer at any length, with as many examples and details as appropriate. The data will be reported anonymously in any future publication. I will conduct the interviews myself and take notes by hand or type. After the interview, I will be happy to show you all my notes, if you wish to check any point for accuracy. I would also stay in touch as the project continues and provide a copy of any resulting publication. All notes will be accessible only by myself and my faculty advisor.

If you have any interest in participating, or at least hearing more details, I would be very happy to send you a few follow-up documents, including my proposal, the interview question sheet, and important information from my university about the "human subject" (interview) portion of the study. I received approval from my Department Chair and U of L's Institutional Review Board to begin this phase of the research before making contact with you.

When it comes to understanding gender and politics, there is no one more informative than speaking to those who understand legislation best- our legislators. Thank you for your time and consideration of this interview request.

Sincerely,

Amanda Allen

Dr. Jasmine Farrier (Faculty Supervisor) 


\section{APPENDIX B}

Amanda Allen

Interview Question Sheet

\section{The Priorities and Accomplishments of Kentucky Legislators: Is there a Gender}

\section{Difference?}

Date:

Name of interview subject:

Location of interview:

Gender:

Party:

Geographical Region:

Legislative Chamber:

Legislative District:

In this study, you will be asked in a private oral interview to answer several questions about your policy priorities and how you perceive legislative success. Please answer as many of the questions as you are comfortable doing. You may answer at any length, with as many examples and details as appropriate to you. The data will be reported anonymously in any future publication. Amanda Allen will take notes by hand or typed while you speak and will be happy to show them to you at the end of the meeting, if you wish to check any point for note accuracy. This interview should last no more than 45 minutes.

\section{Legislative Priorities:}

1. What policy areas do you feel most knowledgeable about and comfortable handling? Why is that?

2. I imagine there are several policy area that are important to you. However, if you had to narrow it down, what would say are your three most important legislative policy priorities? Why?

3. What are the biggest influences on determining your policy priorities?

4. Since you have been in office, what have you done to try to turn your priorities into legislative action? For instance, have you proposed legislation or worked to co-sponsor bills with others?

Legislative Perception of Success:

1. Lawmakers have a variety of goals they wish to accomplish. What does success mean to you in pursuing your legislative priorities?

2. I'm going to read you a list of statements and ask you to indicate how important each has been to your success as a legislator. 
Your personal initiative?

Would you say that it is: 1 (very important) 2 (somewhat important) 3 (neither important nor unimportant) 4 (somewhat unimportant) 5 (very unimportant)

Your past experience as a legislator?

Would you say that it is: 1 (very important) 2 (somewhat important) 3 (neither important nor unimportant) 4 (somewhat unimportant) 5 (very unimportant)

Your professional experience outside the legislature?

Would you say that it is: 1 (very important) 2 (somewhat important) 3 (neither important nor unimportant) 4 (somewhat unimportant) 5 (very unimportant)

Support from staff?

Would you say that it is: 1 (very important) 2 (somewhat important) 3 (neither important nor unimportant) 4 (somewhat unimportant) 5 (very unimportant)

Collaboration with fellow lawmakers on committees?

Would you say that it is: 1 (very important) 2 (somewhat important) 3 (neither important nor unimportant) 4 (somewhat unimportant) 5 (very unimportant)

Collaboration with fellow lawmakers in your party?

Would you say that it is: 1 (very important) 2 (somewhat important) 3 (neither important nor unimportant) 4 (somewhat unimportant) 5 (very unimportant)

Collaboration with fellow lawmakers in the opposing party?

Would you say that it is: 1 (very important) 2 (somewhat important) 3 (neither important nor unimportant) 4 (somewhat unimportant) 5 (very unimportant)

\section{$\underline{\text { Gender }}$}

1. Next, I'm going to read you a statement and ask whether you agree or disagree with it. A legislator's gender affects their success as a legislator. Do you strongly agree, agree, neither agree nor disagree, disagree, or strongly disagree?

1 (strongly agree) 2 (agree) 3 (neither agree nor disagree) 4 (disagree) 5 (strongly disagree)

2. Can you elaborate on the reasoning for answer to the previous question?

3. Earlier, you mentioned as your policy priorities. Which ones, if any at all, do you associate as women's issues? Are there policy areas, if any, that you consider women's issues?

4. In your estimation, how often would you say that women's issues come up when the general assembly is in session?

1 (frequently) 2 (occasionally) 3 (not sure) 4 (rarely) 5 (never) 